\title{
Exploring Deep-Sea Brines as Potential Terrestrial Analogues of Oceans in the lcy Moons of the Outer Solar System
}

\author{
André Antunes $^{1^{*}}$, Karen Olsson-Francis ${ }^{2}$ and Terry J. McGenity ${ }^{3}$ \\ 1State Key Laboratory of Lunar and Planetary Sciences, Macau University \\ of Science and Technology (MUST), Taipa, Macau SAR, China \\ ${ }^{2}$ School of Environment, Earth and Ecosystem Sciences, The Open \\ University, Milton Keynes MK7 6AA, UK \\ ${ }^{3}$ School of Life Sciences, University of Essex, Colchester CO4 3SQ, UK \\ *aglantunes@must.edu.mo
}

DOI: https://doi.org/10.21775/9781912530304.06

\begin{abstract}
Several icy moons of the outer solar system have been receiving considerable attention and are currently seen as major targets for astrobiological research and the search for life beyond our planet. Despite the limited amount of data on the oceans of these moons, we expect them to be composed of brines with variable chemistry, some degree of hydrothermal input, and be under high pressure conditions. The combination of these different conditions significantly limits the number of extreme locations, which can be used as terrestrial analogues. Here we propose the use of deep-sea brines as potential terrestrial analogues to the oceans in the outer solar system. We provide an overview of what is currently known about the conditions on the icy moons of the outer solar system and their oceans as well as on deep-sea brines of the Red Sea and the Mediterranean and their microbiology. We also identify several threads of future research, which would be particularly useful in the context of future exploration of these extra-terrestrial oceans.
\end{abstract}

\section{The icy moons of the Outer Solar System}

Icy moons are natural satellites that are characterised by a surface that is composed predominantly of ice, which may contain a sub-surface ocean, 
and possibly a rocky core of silicate or metallic rocks. In the outer Solar System, icy moons orbit the gaseous planets, Jupiter and Saturn. The icy moons of Jupiter - lo, Europa, Ganymede and Callisto - were discovered by Galileo Galilei in 1610 and are frequently referred to as the Galilean moons of Jupiter (Showman and Malhotra, 1999); whilst Saturn is orbited by numerous icy moons, which include Enceladus, Mimas, Tethys, Dione, and Titan.

The icy moons are of extensive interest for future exploration due to their potential sub-surface oceans. For example, Europa (Kivelson et al., 2000), Ganymede (Kivelson et al., 2002), Callisto (Khurana et al., 1998), and Enceladus (Spencer and Nimmo, 2013) present evidence of a briny ocean under an icy surface. As our understanding of these icy moons evolves so does interest from an astrobiological point of view. The following sections will discuss two of these icy moons, Enceladus and Europa, in more detail.

\section{Enceladus}

\section{Surface}

Enceladus is covered with a thick icy shell that varies in depth dependant on latitude. Based on data from Cassini, modelling has predicted that the ice shell is approximately 18 to $22 \mathrm{~km}$ thick on average, but less than $5 \mathrm{~km}$ at the South Pole region (Cadek et al., 2016). The composition is believed to be almost pure water with spectroscopy data suggesting that it also contains small amounts of carbon dioxide, hydrogen peroxide, light organics, and perhaps ammonium (Brown et al., 2006, Emery et al., 2005). The temperature at the surface at low latitude varies from approximately $-223^{\circ} \mathrm{C}$ at night to $-193^{\circ} \mathrm{C}$ during the day (Howett et al., 2010). The surface has a particularly high albedo (Howett et al., 2010) and contains several regions of cratered and smooth terrain, which may denote differences in their respective age (Squyres et al., 1983a).

In the South Polar Region unique surface features called "tiger stripes" are observed, which are central to present-day geological activity (Spencer and Nimmo, 2013; Spencer et al., 2006). The stripes are the source of thermal activity and associated plume emissions venting from the surface (Squyres et al., 1983a), which were observed by the Cassini flyby mission. The presence of these plumes suggests the existence of a sub-surface ocean consisting of liquid water (Waite et al., 2017) and analysis of the icy grains in the plumes imply that they are rich in sodium (Postberg et al., 2011). The salt-composition is similar to that expected for water that has equilibrated with Enceladus's presumed silicate core (Zolotov, 2007). The plumes may be caused by hydrothermal activity at the ocean floor (Hsu et al., 2015; Waite et al., 2017), which is supported by data from the Cassini mission that shows tidal dissipation in the rocky core. 


\section{Sub-surface ocean}

Contrary to previous assumptions, the ocean of Enceladus is believed to have a global distribution rather than being restricted to polar regions (Patthoff and Kattenhorn, 2011). The energy required to maintain liquid water most likely originates from the dissipation of tidal energy from the friction of the sub-surface ocean with the internal silicate interior (Nimmo et al., 2007).

Information regarding the composition of the ocean has been obtained from plume analysis, which showed that particle emissions are dominated by water ice and is rich in sodium and potassium salts ( 0.5 to $2 \%$ by mass), but also contains sodium bicarbonate/ sodium carbonate (Postberg et al., 2011). The ocean is expected to contain low concentrations of ammonia, methane, carbon dioxide and molecular hydrogen (Waite et al., 2017). These elements are potentially produced as a result of geochemical reactions occurring at the interface of the chondrite-like core and the ocean at temperatures below $100^{\circ} \mathrm{C}$ (Waite et al., 2017). The circulation of the water would drive the chemical evolution of both the rock material and the ocean water, producing a chemical gradient, which could be used by microorganisms to generate energy (Barge and White, 2017). The presence of silica nanoparticles in the plumes is also evidence for hydrothermal reactions occurring in the interior, which may be the source of molecular hydrogen (Sekine et al., 2015).

Based on the chemistry of the plumes, the $\mathrm{pH}$ of the ocean is predicted to be alkaline, with current estimates placing it between 8.5 and 13 (e.g. Postberg et al., 2009; Hsu et al., 2015). These values have been calculated by either modelling the equilibrium reactions at the water-rock interface or by the concentrations of salts in the plumes (Zolotov, 2007; Postberg et al., 2009). The temperature varies within the sub-surface oceans. The estimated temperature at the ocean-ice interface is approximately $-0.15^{\circ} \mathrm{C}$ (Glein et al., 2015); whereas $\mathrm{SiO}_{2}$ nanoparticles in the plumes suggest a minimal localised temperature of $90^{\circ} \mathrm{C}$ at the water-rock interface. Gravimetric measurements have suggested that that rock-ocean and iceoceans interfaces are at depths of $50 \mathrm{~km} \mathrm{(} 5.3 \mathrm{MPa})$ and $35-40 \mathrm{~km}$ (3.6-4.2 MPa) (less et al., 2014). However, values have been estimated to be as high at $10 \mathrm{MPa}$ at the rock-ocean interface (Zolotov, 2007) and 8 $\mathrm{MPa}$ at the ice-ocean interface (Hsu et al., 2015). It should be noted that these pressures are lower than that on Earth due to the gravitational force associated with the icy moons.

\section{Europa}

\section{Surface}

Europa is covered by an icy shell, with a highly debated thickness that is estimated to range between a few $\mathrm{km}$ to over $30 \mathrm{~km}$ (Billings and Kattenhorn, 2005; Quick and Marsh, 2015). The surface of Europa is 
dominated by ridges and chaotic terrain, which is thought to be relatively young, or still geologically active (Squyres et al., 1983b; Carr et al., 1998). These regions indicate locations where resurfacing of material from the sub-surface ocean may have occurred (Hand and Carlson, 2015). The surface is a distinct yellow-brown colour, which has been postulated to result from sulfur chemistry, either from an exogenous or endogenous source (Geissler et al., 1998; Carlson et al., 2009). However, Hand and Carlson suggested that the discolouration might be due to sodium chloride from the sub-surface, which yields a yellow-brown colour when exposed to the radiation conditions present at the surface of Europa (Hand and Carlson, 2015). Observations of the thermal emissions by the Galileo mission showed low latitude diurnal brightness temperatures between $-194^{\circ} \mathrm{C}$ in the Polar Regions and approximately $-143^{\circ} \mathrm{C}$ at the equatorial regions (Spencer et al., 1999). Images from the Hubble Space Telescope suggest the presence of water-vapour plumes, appearing to rise $200 \mathrm{~km}$ above the disk of Europa's solid body, which would indicate transport of material from the interior ocean to the surface (e.g. Ross and Schubert, 1987; Roth et al., 2014; Sparks et al., 2016; Jia et al., 2018). Furthermore, tidal stress has been suggested as playing a role in the opening and closing of fractures at the surface to allow water vapour to be released from the sub-surface ocean (Roth et al., 2014).

\section{Sub-surface ocean}

Magnetometer measurements suggest that Europa has a global-scale ocean (Ross and Schubert, 1987; Kivelson et al., 2000). The formation of this liquid ocean is thought to be due to tidal heating, tidal flexing, and/or to radioactive decay of the silicate core (Ross and Schubert, 1987; Han and Showman, 2010). Based on the expected salinity of the ocean brine the temperature will be at a minimum, $-13^{\circ} \mathrm{C}$ (Zolotov and Kargel 2009), with the maximum temperature occurring at the ocean floor where hydrothermal activity may occur $\left(\sim 90^{\circ} \mathrm{C}\right)$ (Kargel et al., 2000; Zolotov and Kargel, 2009). Therefore, temperatures that are significantly higher than freezing should only exist in porous channels below the seafloor, or close to hydrothermally active regions (Vance and Goodman, 2009). At the ocean floor the pressure has been modelled to be approximately $110 \mathrm{MPa}$ (Hand et al., 2009).

Due to lack of direct measurements of the sub-surface ocean, the chemical composition remains unknown. However, initial experiments and theoretical simulations strongly suggest that the composition of the ice surface is a direct result of the ocean material from below and could thus be used to infer its composition (Kargel et al., 2000). Yet, more recently the chemical species present at the surface (e.g. sulfates) were suggested to be a result of radiation (Hand and Carlson, 2015). Therefore, geochemical models have been used to predict the composition of the salty brine, which results in widely varying compositions. For example, modelling of the initial chondritic composition leads to a magnesium and sulfur-rich ocean (Kargel 
et al., 2000); whereas modelling of the water-to-rock cycling at the silicate seafloor leads to a chloride-rich ocean (Glein and Shock, 2010). The chemical composition of the ocean would influence the $\mathrm{pH}$, which limits our ability to make conclusive predictions in this regard. For example, a brine dominated by sulfate would be acidic and a brine rich in chloride would be basic or neutral (Zolotov, 2007; 2009). Due to surface irradiation and tidal forces associated with Europa it has been postulated that a metastable dynamic state would occur, which could support microbial metabolism. For example, the water-rock interaction at the ocean floor would produce electron-rich energy sources, while oxidants would be produced due to radiolysis at the ice surface (Hand et al., 2004; Russell et al., 2017).

\section{Icy moon analogues}

Terrestrial analogue environments exhibit conditions that are similar to those of planetary bodies and moons in the Solar System (Martins et al., 2017). Historically, the majority of terrestrial analogue sites have been selected for studying Mars. More recently, however, attention has focused on the icy moons with a number of studies using sulfate lakes (e.g. PrietoBallesteros et al., 2003), cold-springs (e.g. Gleeson et al., 2012) and subglacial lakes as analogues for the sub-surface oceans (Garcia-Lopez and Cid, 2017). For example, the hypersaline subglacial lake beneath the Devon ice cap in the Canadian Arctic has been discovered recently and considered as an analogue for the sub-surface ocean of Europa (Rutishauser et al., 2018). However, to fully understand the processes that occur, and the potential life, in the sub-surface oceans of the icy moons an ideal analogue would be terrestrial deep seas. These environments are among the last earthly frontiers for discovery. Many areas of the ocean floor remain inadequately mapped, and new geomorphological features, and several new life forms have been isolated. The discovery and exploration of deep-hypersaline anoxic basins is particularly relevant from an astrobiological perspective, as it shows striking parallels with the oceans of the icy moons of the Outer Solar System.

While detailed information on the exact physical-chemical conditions present in the exooceans of the icy moons of the outer Solar system is still quite limited, we now know that these are brine oceans and likely associated with localized hydrothermal input. Salinity estimates vary but most seem to point to a somewhat lower value than the Earth's oceans, although these have been reported as having a high degree of uncertainty of two orders of magnitude (Lunine, 2017). Furthermore, several authors propose mechanisms that would lead to expected localized significant increases in salinity. Indeed, increase in salinity might arise from brine exclusion during freezing at the interface between the ice crust and the underlying ocean (equivalent to the formation of brine inclusions on marine ice on Earth) or interactions between seawater and rocks at the bottom of these exooceans (Hendrix et al., 2019). Furthermore, strong double diffusive convection processes have been predicted for Europa (Vance and 
Goodman, 2009; Elsenousy et al., 2015), leading us to expect density gradients driven by temperature and salinity. According to some of the possible scenarios proposed by these authors, Europa might have a stratified ocean and precipitation from rising plumes could cause "snowing" effects with precipitation of salt, which would increase the salinity closer to the bottom and might even lead to thick layers of salt deposits.

Deep-hypersaline anoxic basins provide an interesting proxy for several of these conditions and their wide range of physical-chemical conditions allow us to partly circumvent the wide variability of predictions on the physicalchemical settings in these exooceans. The following section will focus on these unusual deep-sea extreme environments and their microbes, with the discussion being centred on the Red Sea and the Mediterranean.

\section{Deep-hypersaline anoxic basins (DHABs)}

\section{Origin and main characteristics}

DHABs are very unusual environments, which combine a unique range of environmental extremes and are regarded as one of the most extreme environments on our planet (e.g. Antunes, 2017; Merlino et al., 2018; Antunes et al., 2019). They were accidentally discovered in the axial region of the Red Sea after the collection of unexpectedly warm and salty deepsea water during an expedition of the RV Albatross in 1947/48 (Bruneau et al., 1953). Further studies led to the identification and description of the first DHAB in the Red Sea (Miller, 1964) and wider surveys identified several additional ones scattered across the central axis of the Red Sea. Similar environments were later detected in the Mediterranean Sea (Cita et al., 1985) and in the Gulf of Mexico (Shokes et al., 1977), with on-going exploration regularly increasing the number of identified DHABs (e.g. Ehrhardt et al., 2005; Yakimov et al., 2013, 2015).

All of these DHABs seem to be associated with tectonic activity in areas of the globe with deeper saline strata formed via evaporation of ancient seas. Such tectonic activity promotes the formation of topographical depressions and exposes these evaporite strata to dissolution and leaching events and formation of brines that accumulate in several of these depressions as a result of their significantly higher density. The sheltered location of the brines together with their higher densities, and very weak deep-sea currents, contribute to very limited mixing with overlying seawater and lead to stable brine bodies with very sharp brine-seawater interfaces, which display drastic transitions in physical-chemical conditions often occurring within the span of a few meters (De Lange et al., 1990a; Eder et al., 2001; van der Wielen et al., 2005; Borin et al., 2009; Antunes et al., 2011d).

The brine-seawater interfaces are very complex environments, with significant shifts in salinity, $\mathrm{O}_{2}$ concentration, $\mathrm{pH}$, and temperature over a relatively small vertical scale. Such transitions provide a variety of 
environmental niches and ideal conditions for the establishment of local redox cycles, which involve biotic input. Furthermore, the density difference occurring at the brine-seawater interface leads to increased particle load by trapping sinking particles and mineral precipitates produced in local redox reactions. The trapping of organic matter combines with the redox gradient to create a variety of electron donor-acceptor couplings that are favourable for microbial generation of energy, making this compartment of the brines the one with the highest activity.

There is extensive discussion about the extent to which these DHABs were formed by leaching of tectonically exhumed halite or by release of relic brines trapped within the evaporites (Vengosh et al., 1998; Camerlenghi, 1990; Cita, 2006), or supercritical heating at great depth of seawater resulting in hydrothermally formed salts and brines (Hovland et al., 2018), with the diverse sources of the brines resulting in distinct chemistries (Table $1)$.

The primary difference between the DHABs of the Red Sea and the eastern Mediterranean Sea is that those in the Mediterranean are generally cooler $\left(\sim 15^{\circ} \mathrm{C}\right)$, which reflects the inherently lower temperature of the deep Eastern Mediterranean $\left(13.5^{\circ} \mathrm{C}\right.$; Tsimplis and Baker, 2000) compared with that of the Red Sea $\left(\sim 21.5^{\circ} \mathrm{C}\right.$; Yao and Hoteit, 2018), as well as a lesser contribution by hydrothermal fluids in the Mediterranean (Cita, 2006). They are also the deepest DHABs at more than 3000 mbsl (Cita, 2006). Overall, the Red Sea DHABs are, perhaps, geochemically less diverse than those of the Mediterranean (based on dissolved ion concentrations) but have more variable temperatures and generally higher concentrations of heavy metals (Antunes et al., 2011d).

\section{Red Sea DHABs}

The DHABs of the Red Sea were formed as a result of the tectonic split of the Arabian and African tectonic plates and re-dissolution of evaporites from the Miocene (mostly composed of halite and anhydrite).

The Red Sea has the highest number of known DHABs, which include: Albatross, Atlantis II, Chain, Conrad, Discovery, Erba, Kebrit, Nereus, Oceanographer, Port Sudan, Shaban, Shagara, Suakin, Valdivia, and Wando Basin (Bruneau et al., 1953; Backer and Schoell, 1972; Pautot et al., 1984; Cochran et al., 1986). Based on their geochemical properties (Table 1), a recent cluster analysis by Schmidt et al. (2015) split the DHABs of the Red Sea into two groups, which could be correlated with the local sedimentary and tectonic setting of the individual deeps.

\section{Red Sea Type 1 Brines - Oceanographer and Kebrit DHABs}

Type 1 brines have high salinity, low $\mathrm{pH}$, low temperature, and low tracemetal concentrations which are probably linked with their high $\mathrm{H}_{2} \mathrm{~S}$ content (e.g. Weber and Gurskii 1982; Schmidt et al., 2003). They are located 
Table 1. Overview of major physical-chemical characteristics of the DHABs of the Red Sea and the Mediterranean Sea.

\begin{tabular}{|c|c|c|c|c|c|c|c|c|}
\hline & $\mathrm{Na}^{+}$ & $\mathrm{Cl}^{-}$ & $\mathbf{M g}^{2+}$ & $\mathbf{K}^{+}$ & $\mathrm{Ca}^{2+}$ & $\mathrm{SO}_{4}{ }^{2-}$ & $\mathrm{pH}$ & $\mathrm{T}\left({ }^{\circ} \mathrm{C}\right)$ \\
\hline \multicolumn{9}{|l|}{ Red Sea } \\
\hline Albatross & 4344.88 & 4608.75 & 48.84 & 55.96 & 111.98 & 14.89 & 6.8 & 23.9 \\
\hline Atlantis II & 4677.73 & 5189.97 & 35.42 & 86.88 & 148.71 & 10.74 & 5.21 & 68.2 \\
\hline Chain & 4800 & 5200 & 36.8 & 66.8 & 143.3 & 8.5 & 6.48 & 53.2 \\
\hline Conrad & 4295.43 & 4619.67 & 101.01 & 67.7 & 24.63 & 48.77 & 6.1 & 23.0 \\
\hline Discovery & 4635.53 & 5021.75 & 36.78 & 84.86 & 144.87 & 10.66 & 6.2 & 44.8 \\
\hline Erba & 2621.99 & 2678.14 & 71.43 & 30.92 & 29.57 & 47.15 & 7.4 & 26.1 \\
\hline Kebrit & 4805.74 & 5135.67 & 121.13 & 36.7 & 56.56 & 20.08 & 5.5 & 23.3 \\
\hline Nereus & 3556.62 & 4131.47 & 64.06 & 77.42 & 230.8 & 11.25 & 7.43 & 30.2 \\
\hline Oceanographer & 4353.37 & 4716.86 & 280.64 & 77.09 & 86.21 & 10.32 & 5.6 & 24.9 \\
\hline Port Sudan & 3784.68 & 3855.22 & 70.89 & 46.5 & 35.63 & 47.77 & 6.43 & 36.2 \\
\hline Shaban (N) & 4784.51 & 4900.52 & 97.96 & 49.29 & 19.74 & 51.57 & 6.0 & 25.3 \\
\hline Suakin & 2416.77 & 2612.84 & 62.87 & 35.42 & 57.14 & 36.05 & 7.85 & 24.6 \\
\hline Valdivia & 4100 & 4600 & 95.3 & 52.0 & 25.0 & 72.0 & 6.21 & 29.8 \\
\hline \multicolumn{9}{|c|}{ Mediterranean Sea } \\
\hline Bannock & 4200 & 5378 & 643.9 & 126.3 & 16.3 & 135.2 & 6.5 & 15.1 \\
\hline Discovery & 840.17 & 10154.29 & 5142.97 & 89.52 & 1 & 110.35 & 4.5 & 14.5 \\
\hline Hephaestus & 93 & 9120 & 4720 & 28 & 2 & 203 & 5.0 & 15.3 \\
\hline Kryos & 1236.32 & 9054.24 & 4402.39 & 84.4 & 1 & 322.71 & 5.4 & 14.5 \\
\hline L'Atalante & 4654.24 & 5302.8 & 658.3 & 368.31 & 7.49 & 333.13 & NA & 14.3 \\
\hline Medee & 4178 & 5259 & 788 & 471 & 2.8 & 201 & 6.7 & 15.4 \\
\hline Thetis & 4760 & 5300 & 604 & 230 & 9 & 265 & NA & 15.1 \\
\hline Tyro & 5300 & 5350 & 71.1 & 19.2 & 35.4 & 52.7 & 6.75 & 14.2 \\
\hline Urania & 3505 & 3730 & 315 & 122 & 31.6 & 107 & 6.8 & 18.3 \\
\hline
\end{tabular}

All chemical composition data provided in mM. NA: Not Available. Data compiled from Antunes et al., 2011d; De Lange et al., 1990b; La Cono et al., 2011; 2019; Merlino et al., 2018; Sass et al., 2001; Schmidt et al., 2015; Van der Wielen et al., 2005; Yakimov et al., 2013; 2015; and references cited therein.

slightly off-axis and controlled by evaporite dissolution rather than contributions from sediment alteration with hydrothermal fluid derived from water/volcanic rock interaction, which appear to be of minor importance.

Red Sea Type 2 Brines - Suakin, Port Sudan, Erba, Albatross, Discovery, Atlantis II, Nereus, Shaban, and Conrad DHABs

These brines are influenced by hydrothermal activity and variable contributions from volcanic/ magmatic rock alteration, which explain e.g. the high concentration of $\mathrm{Mn}, \mathrm{Fe}$, and $\mathrm{Zn}$ and low concentrations of $\mathrm{Mg}$ and 
sulfate (Seyfried, 1987). This hydrothermal influence is strongest in Atlantis II, which has a multi-layered brine and is also the DHAB with highest recorded temperature.

\section{Mediterranean Sea DHABs}

The DHABs of the Mediterranean share clear similarities with those in the Red Sea, although they occur under a different tectonic setting (convergent plate boundary). The source of the brine is underlying evaporites (deposited in the Mediterranean basin during the Messinian Salinity Crisis 5.97 to 5.32 million years ago), mostly from the acme evaporitic stage (5.60 to $5.55 \mathrm{MYA}$ ), which has thick beds of halite with associated minerals (Roveri et al., 2004). However, hydrothermally-derived salt and brine has also been proposed as an alternative source (Hovland et al., 2018).

The Mediterranean DHABs are (in order of discovery): Tyro (Jongsma et al., 1983; De Lange et al., 1990b), Bannock (Scientific staff of Cruise Bannock 1984-12, 1985; De Lange et al., 1990b), Urania (Medriff Consortium, 1995), L'Atalante (Medriff Consortium, 1995), Discovery (Medriff Consortium, 1995), Thetis (La Cono et al., 2011), Medee (Yakimov et al., 2013), Kryos (Yakimov et al., 2015), and Hephaestus (La Cono et al., 2019). Their chemical differences (outlined in Table 1) allow us to split them into three groups.

\section{Mediterranean Type 1 Brines - Urania DHAB}

Urania DHAB is $>100 \mathrm{~m}$ deep, filled with $\mathrm{NaCl}$-rich brine, similar to type 2 brines but with lower salinity (about six times seawater salinity). Additional features include a second stable but less pronounced chemocline (in addition to the brine-seawater interface), as well as very high sulfide concentrations of up to $16 \mathrm{mM}$ (van der Wielen et al., 2005; Borin et al., 2009). This makes Urania brine among the most sulfidic water body on Earth.

An intriguing feature of the deeper western part of the horse-shoe shaped Urania DHAB is the high-temperature bubbling mud vent $\left(45^{\circ} \mathrm{C} ; 10 \%\right.$ salinity) beneath the relatively cold Urania brine $\left(16^{\circ} \mathrm{C} ; 27 \%\right.$ salinity) resulting in a reverse halocline (Yakimov et al., 2007a).

Mediterranean Type 2 Brines - Bannock, L'Atalante, Medee, Thetis DHABs Mediterranean Type 2 Brines are dominated by $\mathrm{Na}^{+}$and $\mathrm{Cl}^{-}$ions, have an ionic composition that largely reflects concentrated seawater, and have a salinity that is about eight times higher than that of seawater, which differentiates them from Mediterranean Type 1 Brines. The proximity of the different basins seems to have little effect on chemical composition. For example, L'Atalante basin (Type 2) is close to Urania basin (Type 1) and Discovery basin (Type 3), whereas it is more distant from other Type-2 brines (Merlino et al., 2018). 
Mediterranean Type 3 Brines - Discovery, Hephaestus and Kryos DHABs DHABs within this group are perhaps the most intriguing of all owing to the exceptionally high $\mathrm{MgCl}_{2}$ concentration of their brines $(\sim 5 \mathrm{M})$, which are presumably derived from bischofite $\left(\mathrm{MgCl}_{2} \cdot 6 \mathrm{H}_{2} \mathrm{O}\right)$ that forms in the very latest stages of seawater evaporitic cycles (see La Cono et al., 2019). This high concentration of the divalent ion $\mathrm{Mg}^{2+}$ coupled with $\mathrm{Cl}^{-}$results in brines that are below the currently accepted water activity $\left(A_{w}\right)$ limit of life, which has recently decreased from the long-established value of 0.605 (Stevenson et al., 2015) to 0.585 (Stevenson et al., 2016), as well as brines that are extremely destabilising towards biological macromolecules (i.e. chaotropic) (Hallsworth et al., 2007). The presence of life in such hostile brines would alter our perception of life's limits on Earth and elsewhere.

\section{Life in Deep Hypersaline Anoxic Basins}

\section{Microbial isolates}

The Red Sea DHABs were originally declared sterile in the 1960s (Watson and Waterbury, 1969) and left mostly unexplored for several decades. Later studies, particularly based on molecular-based methodologies, have shown them to be teeming with life.

Work in the DHABs of the Red Sea has proven particularly fruitful in the isolation of microbes representing novel higher taxa. These include Flexistipes sinusarabici (the first representative of the phylum Deferribacteres; Fiala et al., 1990; Garrity et al., 2001), Salinisphaera shabanensis (representing the new family Salinisphaeraceae within the Gammaproteobacteria; Antunes et al., 2003; Vetriani et al., 2014), and Haloplasma contractile (the first representative of the order Haloplasmatales and likely representing a novel bacterial phylum; Antunes et al., 2008a). Further fully described taxa include several novel species and a new genus, and have been often associated with whole-genome sequencing (e.g. Antunes et al., 2008b; 2011b; Zhang et al., 2017a, 2017b; 2017c; see Table 2 and Table 3 for a full overview). Several additional studies reported the isolation of further microbial strains, unfortunately never fully described but still providing us with further insights into the cultivated microbial diversity of these locations. (e.g. Eder et al., 2001; Sagar et al., 2013a, 2013b; Zhang et al., 2016a, 2016b; see Table 2 and Table 3 for a full overview).

The exploration of the DHABs of the Mediterranean has led to the description of one new species: the archaeon Natrinema salaciae (Albuquerque et al., 2012). Studies on the Mediterranean have frequently focused on cultivation-independent approaches or have reported on the isolation of microbial strains that have not been fully described. Enrichment campaigns by Daffonchio et al. (2006) isolated fermentative halophiles such as Halanaerobiales, a Halothiobacillus that aerobically oxidised thiosulfate with $\mathrm{CO}_{2}$ as sole carbon source over a $\mathrm{NaCl}$ range of $0.5-23 \%$, 
Table 2. Proteobacteria isolated from DHABs of the Red Sea and the Mediterranean Sea.

\begin{tabular}{|c|c|c|c|c|c|c|c|}
\hline $\begin{array}{l}\text { Class } \\
\text { Family }\end{array}$ & Genus/Species/Strain & \multicolumn{3}{|c|}{ Origin } & Description & $\begin{array}{l}\text { Gen- } \\
\text { ome }\end{array}$ & Ref \\
\hline \multicolumn{8}{|l|}{ Alphaproteobacteria } \\
\hline \multirow[t]{7}{*}{ Rhodobacteraceae } & strain GMDJE10F1 & Med & Bannock & $\mathrm{BSI}$ & - & - & 1 \\
\hline & Ponticoccus marisrubri & RS & Erba & BSI & new species & + & 2 \\
\hline & Ruegeria marisrubri & RS & Erba & $\mathrm{BSI}$ & new species & + & 3 \\
\hline & Ruegeria profundi & RS & Erba & BSI & new species & + & 3 \\
\hline & Roseobacter sp. & Med & Urania & $\mathrm{BSI}$ & - & - & 4 \\
\hline & Sediminimonas sp. & RS & Kebrit & $\mathrm{BSI}$ & - & - & 5 \\
\hline & Sulfitobacter sp. & RS & Kebrit & $\mathrm{BSI}$ & - & - & 5 \\
\hline Rhodospirillaceae & ND & Med & Urania & $\mathrm{BSI}$ & - & - & 4 \\
\hline Erythrobateraceae & Erythrobacter sp. & Med & Urania & $\mathrm{BSI}$ & - & - & 4 \\
\hline \multicolumn{8}{|l|}{ Betaproteobacteria } \\
\hline Nitrosomonadaceae & Nitrosovibrio sp. & Med & Bannock & Sed & - & - & 6 \\
\hline \multicolumn{8}{|c|}{ Gammaproteobacteria } \\
\hline \multirow[t]{2}{*}{ Alcanivoracaceae } & Alcanivorax sp. & Med & Bannock & BSI & - & - & 1 \\
\hline & Fundibacter sp. & Med & Urania & $\mathrm{BSI}$ & - & - & 4 \\
\hline \multirow[t]{9}{*}{ Alteromonadaceae } & \multirow[t]{4}{*}{ Alteromonas spp. } & \multirow[t]{4}{*}{ Med } & Bannock & BSI & - & - & 1 \\
\hline & & & Urania & $\mathrm{BSI}$ & - & - & 4 \\
\hline & & & L'Atalante & $\mathrm{BSI}$ & - & - & 7 \\
\hline & & & Discovery & $\mathrm{BSI}$ & - & - & 7 \\
\hline & \multirow[t]{4}{*}{ Marinobacter spp. } & \multirow[t]{2}{*}{ Med } & Bannock & $\mathrm{BSI}$ & - & - & 1 \\
\hline & & & Urania & $\mathrm{BSI}$ & - & - & 4 \\
\hline & & RS & Erba & BSI & - & - & 5 \\
\hline & & RS & Nereus & $\mathrm{BSI}$ & - & - & 8 \\
\hline & Marinobacter salsuginis & RS & Shaban & $\mathrm{BSI}$ & new species & - & 9 \\
\hline Colwelliaceaea & Isolate S11L1B & RS & Shaban & BSI & - & - & 10 \\
\hline Enterobacteriaceae & Salmonella sp. & Med & Bannock & BSI & - & - & 1 \\
\hline \multirow[t]{8}{*}{ Halomonadaceae } & \multirow[t]{5}{*}{ Halomonas spp. } & \multirow[t]{2}{*}{ Med } & Bannock & $\mathrm{BSI}$ & - & - & 1,7 \\
\hline & & & Urania & $\mathrm{BSI}$ & - & - & 4,7 \\
\hline & & \multirow[t]{3}{*}{ RS } & Erba & BSI & - & - & 8 \\
\hline & & & Kebrit & $\mathrm{BSI}$ & - & - & 5,8 \\
\hline & & & Nereus & $\mathrm{BSI}$ & - & - & 5,8 \\
\hline & \multirow[t]{3}{*}{ Chromohalobacter sp. } & \multirow[t]{3}{*}{ RS } & Atlantis II & $\mathrm{BSI}$ & - & - & 5 \\
\hline & & & Discovery & BSI & - & - & 5,8 \\
\hline & & & Kebrit & Sed & - & - & 5 \\
\hline \multirow[t]{3}{*}{ Halothiobacillaceae } & \multirow[t]{3}{*}{ Halothiobacillus spp. } & \multirow[t]{3}{*}{ Med } & Bannock & BSI & - & - & 1 \\
\hline & & & Urania & $\mathrm{BSI}$ & - & - & 7 \\
\hline & & & Urania & Sed & - & - & 11 \\
\hline
\end{tabular}




\begin{tabular}{|c|c|c|c|c|c|c|c|}
\hline \multirow[t]{6}{*}{ Idiomarinaceae } & \multirow[t]{6}{*}{ Idiomarina spp. } & RS & Discovery & $\mathrm{BSI}$ & - & - & 5 \\
\hline & & RS & Erba & BSI & - & - & 5,8 \\
\hline & & RS & Kebrit & $\mathrm{BSI}$ & - & - & 5 \\
\hline & & RS & Nereus & $\mathrm{BSI}$ & - & - & 5 \\
\hline & & RS & Shaban & BSI & - & - & 12 \\
\hline & & Med & Bannock & $\mathrm{BSI}$ & - & - & 1 \\
\hline Oceanospirillaceae & Oceanospirillum sp. & Med & Urania & BSI & - & - & 4 \\
\hline Pseudoalteromonadaceae & Pseudoalteromonas sp. & Med & Bannock & $\mathrm{BSI}$ & - & - & 1 \\
\hline \multirow[t]{4}{*}{ Pseudomonadaceae } & \multirow[t]{4}{*}{ Pseudomonas spp. } & RS & Suakin & Sed & - & - & 13 \\
\hline & & \multirow[t]{3}{*}{ Med } & Bannock & BSI & - & - & 1 \\
\hline & & & Urania & $\mathrm{BSI}$ & - & - & 4,14 \\
\hline & & & Bannock & Sed & - & - & 6 \\
\hline Salinisphaeraceae & $\begin{array}{l}\text { Salin is ph a era } \\
\text { shabanensis }\end{array}$ & RS & Shaban & BSI & new order & + & 15 \\
\hline Vibrionaceae & Vibrio sp. & Med & Bannock & $\mathrm{BSI}$ & - & - & 1 \\
\hline \multicolumn{8}{|l|}{ Deltaproteobacteria } \\
\hline Desulfovibrionaceae & Desulfovibrio sp. & RS & Atlantis II & $\mathrm{BSI}$ & - & - & 16 \\
\hline Cystobacteraceae & ND & Med & Urania & $\mathrm{BSI}$ & - & - & 4 \\
\hline \multicolumn{8}{|l|}{ Epsilonproteobacteria } \\
\hline Campylobacteraceae & Sulfurospirillum $\mathrm{sp}$. & Med & Bannock & $\mathrm{BSI}$ & - & - & 1 \\
\hline
\end{tabular}

Med, Mediterranean; RS, Red Sea; BSI, Brine-seawater interface; Sed, Sediment.; ND: Not determined; Data from: 1, Daffonchio et al., 2006; 2, Zhang et al., 2017a; 3, Zhang et al., 2017b; 4, Sass et al., 2001; 5, Sagar et al., 2013b; 6, Rodondi et al., 1996; 7, Borin et al., 2008; 8, Sagar et al., 2013a; 9, Antunes et al., 2007; 10 Eder et al., 2002; 11, Sorokin et al., 2006; 12, A. Antunes, M. Taborda and M.S. da Costa (unpublished); 13, Heitzer and Ottow, 1976; 14, Brusa et al., 2001; 15, Antunes et al., 2003; 16, Trüper, 1969.

as well as members of the Epsilonprotobacteria and the Bacteroidetes. A later study by Sass et al. (2008) reports on a large collection of over 80 strains obtained from several Mediterranean DHABs and including Bacilluslike isolates, and a few Halomonas and Alteromonas. More recent, noteworthy isolation and description results include: i) a strain of Halanaeroarchaeum sulfurireducens, an unusual sulfur-reducing and acetate-utilising haloarchaeon obtained from Medee DHAB, ii) a strain closely related to the Red Sea DHAB Halorhabdus tiamatea (Werner et al., 2014), and iii) the description of a three-component microbial consortium from Thetis DHAB (consisting of Halobacteroides, Methanohalophilus, and Halanaerobium), which linked anaerobic glycine betaine degradation with methanogenesis (La Cono et al., 2015).

\section{Molecular-based studies}

The original misconception of DHABs as sterile environments was drastically revised after the pioneering $16 \mathrm{~S}$ rRNA gene phylogenetic studies by Eder et al., (1999, 2001, 2002). These studies uncovered thriving microbial communities and detected several bacterial and archaeal sequence groups which were completely new to Science, which were later 
Table 3. Non-proteobacterial prokaryotes isolated from DHABs of the Red Sea and the Mediterranean Sea.

\begin{tabular}{|c|c|c|c|c|c|c|c|}
\hline $\begin{array}{l}\text { Class } \\
\text { Family }\end{array}$ & Genus/Species/Strain & \multicolumn{3}{|c|}{ Origin } & Description & Genome & Ref \\
\hline \multicolumn{8}{|l|}{ Actinobacteria } \\
\hline Microbacteriaceae & Microbacterium sp. & Med & Urania & BSI & - & - & 1 \\
\hline Micrococcaceae & Arthrobacter sp. & Med & Urania & BSI & - & - & 1 \\
\hline \multicolumn{8}{|l|}{ Bacilli } \\
\hline \multirow[t]{2}{*}{ Staphylococcaceae } & Staphylococcus sp. & Med & Bannock & Sed & - & - & 2 \\
\hline & Staphylococcus sp. & RS & Kebrit & Sed & & & 3 \\
\hline \multirow[t]{14}{*}{ Bacillaceae } & \multirow[t]{6}{*}{ Bacillus spp. } & \multirow[t]{6}{*}{ Med } & L'Atalante & Sed & - & - & 4 \\
\hline & & & \multirow[t]{2}{*}{ Bannock } & Sed & - & - & 4 \\
\hline & & & & BSI & - & - & 5,6 \\
\hline & & & Urania & Sed & - & - & 4 \\
\hline & & & \multirow[t]{2}{*}{ Discovery } & BSI & - & - & 5 \\
\hline & & & & Sed & - & - & 4 \\
\hline & \multirow[t]{3}{*}{ Halobacillus spp. } & RS & Kebrit & Sed & - & - & 7 \\
\hline & & \multirow[t]{2}{*}{ Med } & L'Atalante & BSI & - & - & 5 \\
\hline & & & Urania & Sed & - & - & 4 \\
\hline & Pontibacillus sp. & Med & L'Atalante & Sed & - & - & 4 \\
\hline & Pontibacillus sp. & Med & Urania & Sed & - & - & 4 \\
\hline & Thalassobacillus sp. & Med & Bannock & Sed & - & - & 4 \\
\hline & \multirow[t]{2}{*}{ Virgibacillus sp. } & Med & Bannock & Sed & - & - & 4 \\
\hline & & RS & Nereus & B & - & - & 3 \\
\hline \multicolumn{8}{|l|}{ Clostridia } \\
\hline \multirow[t]{3}{*}{ Halanaerobiaceae } & \multirow[t]{3}{*}{ Halanaerobium spp. } & \multirow[t]{2}{*}{ RS } & Kebrit & BSI & - & - & 8 \\
\hline & & & Shaban & BSI & - & - & 9 \\
\hline & & Med & Bannock & BSI & - & - & 6 \\
\hline \multicolumn{8}{|l|}{ Cytophagia } \\
\hline Cytophagaceae & Cytophaga sp. & Med & Bannock & BSI & - & - & 6 \\
\hline \multicolumn{8}{|l|}{ Deferribacteres } \\
\hline Deferrribacteraceae & Flexistipes sinusarabici & RS & Atlantis II & BSI & new phylum & + & 10 \\
\hline \multicolumn{8}{|c|}{ Firmicutes/ Mollicutes } \\
\hline Haloplasmataceae & Haloplasma contractile & RS & Shaban & BSedl & new order & + & 11 \\
\hline \multicolumn{8}{|l|}{ Flavobacteria } \\
\hline \multirow[t]{2}{*}{ Flavobacteriaceae } & ND & Med & Urania & BSI & - & - & 1 \\
\hline & Zunongwangia sp. & RS & Atlantis II & BSI & - & - & 3 \\
\hline \multicolumn{8}{|l|}{ Halobacteria } \\
\hline Halobacteriaceae & Halorhabdus tiamatea & RS & Shaban & BSedl & new species & + & 12 \\
\hline \multirow[t]{4}{*}{ Haloferacaceae } & Halanaeroarchaeum sp. & Med & Medee & B & - & + & 13 \\
\hline & Haloferax marisrubri & RS & Discovery & BSI & new species & + & 14 \\
\hline & Haloferax profundi & RS & Discovery & BSI & new species & + & 14 \\
\hline & Haloprofundus marisrubri & RS & Discovery & BSI & new genus & + & 15 \\
\hline Natrialbaceaea & Natrinema salaciae & Med & Medee & B & new species & + & 16 \\
\hline
\end{tabular}

Med, Mediterranean; RS, Red Sea; BSI, Brine-seawater interface; B, Brine; BSedI, Brine-sediment interface; Sed, Sediment ND: Not determined; Data from: 1, Sass et al., 2001; 2, Rodondi et al., 1996; 3, Sagar et al., 2013b; 4, Sass et al., 2008 ; 5 Borin et al., 2008; 6, Daffonchio et al., 2006; 7, Sagar et al., 2013a; 8, Eder et al., 2001; 9, Eder et al., 2002; 10, Fiala et al., 1990; 11, Antunes et al., 2008a; 12, Antunes et al., 2008b; 13, Messina et al., 2016; 14, Zhang et al., submitted; 15, Zhang et al., 2017c; 16, Albuquerque et al., 2012.

further expanded by similar studies in the Mediterranean DHABs (e.g. van der Wielen et al., 2005; Daffonchio et al., 2006). Some of these new sequence groups seemed to be specific to individual brines, while others (e.g., KB1, MSBL1) were detected in multiple DHABs both in the Red Sea and the Mediterranean (reviewed in Antunes et al., 2011d). Such a widespread distribution pointed to a high degree of adaptation of these new groups to life in such unique settings.

More recent years generated a considerable amount of data linked with further molecular-based studies, whole-genome sequencing, single-cell 
genomics, and metagenomics. These studies have confirmed the vertical stratification of microbial and viral communities across the brine-seawater interface and offered important insights into the taxonomic and physiological diversity of the brine-seawater interface and the sediments of DHABs (e.g. Antunes et al., 2015; Bougouffa et al., 2013). Significant contributions were made in the clarification of microbial groups involved in sulfate reduction, methanotrophy, methanogenesis and in several aspects of the Carbon, and the Nitrogen cycle (e.g. Yakimov et al., 2007b; La Cono et al., 2011; Siam et al., 2012; Abdallah et al., 2014; Pachiadaki et al., 2014; Guan et al., 2015; Ngugi et al., 2015, 2016; Sorokin et al., 2016).

Whole-genomic sequencing projects have provided some much-needed data on isolated strains from several of the Red Sea DHABs (Table 2 and Table 3), while single-cell genomics efforts based both on Red Sea and Mediterranean samples provided relevant insights into non-cultivated strains from the bacterial KB1 group and the euryarchaeal MSBL1 and SA1 groups (Yakimov et al., 2013; La Cono et al., 2015; Mwirichia et al., 2016; Nigro et al., 2016; Ngugi and Stingl, 2018), which helped to clarify their physiology and might assist in their cultivation (see sections below).

Further insights into the Life in DHABs

Life in the DHABs is increasingly seen as more complex than anticipated, extending past its prokaryotic communities, with first insights available both on their viral and eukaryote communities.

Metagenomic-based analysis on samples from the Red Sea DHABs gave us some clues on viral diversity and community structure, and revealed that viral communities are stratified along the brine-seawater interface (Antunes et al., 2015), similarly to what had been previously reported for prokaryotes.

In the Mediterranean DHAB, sediments were shown to have viral abundances similar to oxic deep-sea sediments (Danovaro et al., 2005), and had high levels of viral infection, resulting in the release of large amounts of prokaryote DNA (Corinaldesi et al., 2014). Viral lysis, rather than grazing by eukaryotes, was proposed to be the main top-down control of prokaryotes in DHAB sediments, as well as a major means of recycling nutrients (Corinaldesi et al., 2014).

The uncovering of eukaryotic life associated with DHABs started with the molecular-based detection of an incredibly diverse and novel range of protists (mostly composed of dinoflagellates, ciliates and other alveolates, as well as fungi) present in Bannock and Discovery, in the Mediterranean Sea (Edgcomb et al., 2009). Danovaro et al. (2010) reported three novel species of the animal phylum Loricifera in L'Atalante DHAB sediment, proposing that they were active and thus the first described metazoans seemingly completing their life cycle in permanently anoxic conditions 
(Danovaro et al., 2016). Our knowledge of eukaryotes associated with DHABs has further escalated with the discovery of macrofauna in a few DHABs in the Red Sea. These findings include: the description of a new genus of bivalve (Oliver et al., 2015), the detection of enriched zooplankton and discovery of fish apparently feeding on the thick particle load present at the brine-seawater interface (Kaartvedt et al., 2016; Vestheim and Kaartvedt, 2016). This rich macrofauna associated with some of the investigated DHABs is in contrast with the extremely poor benthos usually reported for the Red Sea and has been suggested to be linked with increased microbial load and activity in the brine-seawater interfaces (Vestheim and Kaartvedt, 2016).

Despite these recent advances, DHAB research into these two fields is still in its infancy. Further efforts are essential to understand the likely grazing effects and complex trophic interactions between the viral, prokaryotic, and the eukaryotic components of these ecosystems.

\section{Microbiology and geochemistry of the DHABs}

The link between local geochemistry of the brines and their microbiota often predated the first data from microbial studies on several DHABs. Indeed, geochemical data hinted at biogenic sulfate reduction in sulfideforming processes as well as biotic methane oxidation occurring at the brine-seawater interface (Blum and Puchelt, 1991; Faber et al., 1998). Complex redox cycles involving iron and manganese were also postulated to occur in the brine-seawater interface of several DHABs of the Red Sea (Stoffers et al., 1998).

In recent years we have accumulated increasing support for the existence of microbes associated with sulfate reduction, acetogenesis, methanogenesis, autotrophic, and heterotrophic activity, as well as different steps of the nitrogen cycle, including AnAmmOx by Planctomyces (Borin et al., 2009; 2013; Speth et al., 2017) and ammonia oxidation by Thaumarchaeota (Ngugi et al., 2015). These processes have been recently reviewed by Merlino et al. (2018) and Antunes et al. (2019), and are outside the direct scope of this review. The topic of methanogenesis in DHABs has been reviewed by McGenity and Sorokin (2018), but will be discussed briefly in the following section, as methane and other volatile compounds could be detected remotely to inform on the possibility of life in icy moons, as is currently being done with the NOMAD detector on the Mars Trace Gas Orbiter (Vandaele et al., 2015).

\section{Methanogenesis in the DHABs}

Early investigators of the Red Sea DHABs, such as the Kebrit and Shaban deeps, suspected the presence of methanogens based on archaeal biomarkers (Michaelis et al., 1990) and euryarchaeal 16S rRNA gene amplicons (Eder et al., 2002), both of which could derive from nonmethanogenic Archaea. There is also evidence for methylotrophic 
methanogenesis in Mediterrenean DHABs due to the common, but inconsistent, detection or isolation of Methanohalophilus sequences (Hallsworth et al., 2007; Yakimov et al., 2007b; Yakimov et al., 2015; La Cono et al., 2015; McGenity and Sorokin, 2018), as well as demonstration of the osmolyte and compatible solute, glycine betaine, fuelling methane production via fermentation to methylamines (Yakimov et al., 2013; La Cono et al., 2015). In the Mediterranean DHABs methane production rates $\left(\mu \mathrm{M} \mathrm{CH}_{4} \mathrm{~d}^{-1}\right.$ ) of 85.8 (Urania), 16.9 (l'Atalante), 4.2 (Bannock) and 2.6 (Discovery) were detected (van der Wielen et al., 2005; Borin et al., 2009). The most abundant uncultivated archaeal clones (termed MSBL-1) in most of these four basins (van der Wielen et al., 2005), the Urania hydrothermal mud vent (Yakimov et al., 2007a), Thetis DHAB (La Cono et al., 2011), Medee DHAB (Yakimov et al., 2013) and Kryos DHAB (Yakimov et al., 2015), are phylogenetically related to methanogens. This observation, coupled with coincident methane production and/or detection of mcrA transcripts, together with the occasional absence of known methanogenic taxa (Yakimov et al., 2013), led to the suggestion that Candidate Division MSBL-1 Archaea may be methanogens. However, this supposition is not supported by a single-cell genomics analysis of MSBL-1, where the core methanogenesis genes were not detected, and pathway analysis suggest a mixotrophic lifestyle, fermenting glucose or, in the absence of organic carbon, fixing $\mathrm{CO}_{2}$ (Mwirichia et al., 2016).

So, which microbes are carrying out methanogenesis (in addition to Methanohalophilus when present)? Several studies from the Red Sea now report the presence of methanogenesis and methanogens in the brines and the brine-seawater interface (Antunes et al., 2011d). Guan et al. (2015), for example, detected mcrA genes in several of the interfaces, finding typical halophilic methylotrophic genera Methanohalophilus and Methanococcoides, as well as phylotypes similar to Methanomassiliicoccales, which were also detected in Kryos DHAB (Yakimov et al., 2015). Methanomassiliicoccales is a methanogenic order in the Thermoplasmata that can reduce methylamines and methanol with hydrogen ("methyl reduction"; Borrel et al., 2014), although, currently, only non-halophilic members of this order have been characterized. Arguably the most interesting group of halophilic methanogens is the Methanonatronarchaeia (SA1), which were isolated from anoxic hypersaline environments and shown to carry out methanogenesis by methyl reduction as with the Methanomassiliicoccales (Sorokin et al., 2017). The methyl-reduction pathway is distinguished from methylotrophic methanogenesis, as the $C_{1}$ methylated compounds are used only as electron acceptors while $\mathrm{H}_{2}$ is the external electron donor (Sorokin et al., 2017). Comparison of sequences from Archaea in the DHABs revealed that the uncultivated Candidate Division Shaban Archaea (SA1), which is commonly detected in Red Sea and Mediterranean DHABs (Eder et al., 2002; Yakimov et al., 2013; Merlino et al., 2018; McGenity and Sorokin, 2018), is closely related to Methanonatronarchaeia. Thus, this type of methanogenesis may be 
quantitatively important in the DHABs. Ngugi and Stingl (2018), however, added a note of caution when they carried out single-cell genomic analysis on SA1 cells, and revealed no core methanogenesis genes. However, there is a lot of diversity in the SA1 group, and the genome-sequenced lineage had only $93 \%$ identity in 16S rRNA sequence to Methanonatronarchaeia (Ngugi and Stingl, 2018). Further cultivationdependent and -independent explorations of SA1 group Archaea are required to understand the metabolic diversity within this lineage.

In the context of detecting methane from subterranean hypersaline oceans on icy moons it is important to consider that a high proportion may be microbially oxidised before entering the atmosphere. There is evidence for anaerobic oxidation of methane (AOM) in the DHABs, primarily via detection of sequences from uncultured Anaerobic Methane oxidizers Group 1 (ANME-1) (van der Wielen et al., 2005; Daffonchio et al., 2006; Lloyd et al., 2006; Yakimov et al., 2007a, b; La Cono et al., 2011; Pachiadaki et al., 2014). Indeed ANME-1 seem to be the main group carrying out AOM in a wide range of anoxic hypersaline environments (McGenity and Sorokin, 2018). The methane-oxygen counter gradients in DHAB brine-seawater interfaces are conducive to aerobic methane oxidation, and carbon isotope analyses suggest its occurrence in Atlantis II, Discovery and Kebrit DHABs from the Red Sea (Faber et al., 1998; Schmidt et al., 2003), and Type-I methanotrophs (and a small proportion of Type-II methanotrophs) were detected in the brine-seawater interfaces of the aforementioned DHABs (Abdallah et al., 2014).

Further discussions on the feasibility of specific types of microbial metabolism are obviously hampered by the limited amount of actual data on the physical-chemical conditions on these exooceans and is outside the scope of this paper. Nonetheless, it is worth noting that a few authors have been looking into the possibility of microbial activity occurring under predicted exoocean conditions. A relevant example is the study by Taubner et al. (2018), where methane production by the methanogenic archaeal species Methanothermococcus okinawensis under putative Enceladus-like conditions was tested and confirmed.

\section{Future research}

The limits of life

Studying the limits of life is one of the main pillars of Astrobiology. The DHABs provide an opportunity to explore the impact of multiple extremes on microbes, especially the interactions of high pressure and high salinity, including both kosmotropic and chaotropic salts. It is well known that microbial activities are influenced by high pressure (Tamburini et al., 2013) and high salinity (Oren, 2011), but synergistic and antagonistic effects on microbes of multiple environmental stressors, despite being the norm, requires much more in-depth investigation in order to predict biological 
processes on Earth and elsewhere (Harrison et al., 2013; Robinson and Mikucki, 2018). The classic experiments by Yayanos (1986) investigated the interaction of temperature and pressure on the growth rate of isolates, while Kaye and Baross (2004) showed improved growth of Halomonas strains under high-pressure at intermediate, compared with low, salinities. However, there have been few systematic studies investigating polyextremophily, and only modest mechanistic understanding has been obtained, e.g. compatible solutes have been proposed to protect cellular macromolecules from both high salt and pressure stress (Yancey, 2004). In order to understand the interacting effects of those multiple extremes that are most relevant to DHABs and icy-moon brines, a much broader range of microbes and communities must be investigated, especially those that are native to the DHABs. To date, no microbes from the DHABs have been isolated under high hydrostatic pressure, despite evidence from metagenomic expression of esterases, which exhibited optimal function at high hydrostatic pressure and salinity, indicating that they probably derived from piezophiles (Ferrer et al., 2005).

It is known that chaotrope-induced cellular damage can be offset (Hallsworth et al., 2007) and growth enhanced (Zajc et al., 2014; Lima de Alves et al., 2015) by adding kosmotropic solutes to chaotropic solutions/ media, which reduces the water activity but counterbalances the chaotropicity, thus demonstrating that chaotropic-solute-induced destabilisation of macromolecules is a key growth-limiting factor. Despite their hostile chemistry, there is some evidence of microbial activity in both Discovery (van der Wielen et al., 2005) and Kryos DHABs (Yakimov et al., 2015; Steinle et al., 2018), but no evidence to date of life in the youngest (700-year-old) $\mathrm{MgCl}_{2}$-dominated Hephaestus $\mathrm{DHAB}$ beyond $2.97 \mathrm{M} \mathrm{MgCl}_{2}$ (La Cono et al., 2019). Therefore, it will be important to understand which microbes may be performing these activities and how they protect themselves against extremely chaotropic brines. Equally, an improved understanding of the compensatory effects of chaotropic and kosmotropic salts (Hallsworth et al., 2007), and differential microbial adaptations to both types of salts, are needed to predict where life will occur, particularly given the uncertainty of the ionic compositions of icy-moon brines (Marion et al., 2003). Ultimately, the ionic composition (balance of kosmotropes and chaotropes) as well as the overall ionic strength of brines elsewhere in the solar system, together with the physical conditions (pressure, temperature etc.) and microbial adaptations to counter these effects, will be key to determining brine habitability (Hallsworth et al., 2007; Fox-Powell et al., 2016). To this end the Mediterranean type-3 DHABs, rich in $\mathrm{MgCl}_{2}$, provide ideal environments to explore the water activity and chaotropicity limits of life, and potentially to find obligate chaophiles.

\section{Source of microbial strains for exposure experiments}

The use of exposure experiments and testing the resilience of several microbial strains to stressful conditions (equivalent to those found outside 
our planet) has been a strong focus of recent research as highlighted by several dedicated large-scale research projects (e.g. BIOMEX-Biology and Mars experiment, MEXEM- Mars exposed extremophile mixture, IceXposelcy exposure of microorganisms) and discussed by Martins et al. (2017). These experiments are a vital source of data for discussions in Astrobiology, namely on the feasibility of Life outside our planet and on Planetary Protection.

The testing of microbes obtained from extreme terrestrial analogues has been suggested as particularly advantageous as they were hypothesized to have highly effective cellular and molecular adaptations and repair mechanisms which would allow them to better withstand conditions present in their extra-terrestrial counterparts (currently being tested as part of the MEXEM project). In this context, microbes isolated from DHABs (Table 2 and Table 3) constitute a rich source of interesting new targets for exposure experiments and should be prioritized in future studies. The availability of microbial strains representing novel higher-ranked taxonomic groups would significantly extend the range of tested taxa and constitute a relevant source of new data. Furthermore, DHABs' strains belonging to previously known taxa would provide an interesting target for comparative studies which would: a) pair them with closely-related strains isolated from different environments and b) look into potential differences in their resilience when exposed to stress. The existence of genomic data for many of the strains isolated from DHABs (Table 2 and Table 3) would further facilitate a more in-depth analysis.

\section{Long-term viability and preservation: microbes and biomolecules}

As is frequently the case when surveying previously uncharted extreme environments, the microbial exploration of DHABs has uncovered several novel phylogenetic groups. Surprisingly, several of these novel groups seem to be DHAB-specific and have a very wide-spread distribution, being consistently detected in brines of the Red Sea and the Mediterranean (e.g. $\mathrm{KB} 1, \mathrm{MSBL} 1$, and SA2 phylogenetic groups), despite the isolation imposed by their geographical location and by the nature of the brines. Previous studies on haloarchaea, the most extreme of halophiles, pointed to their apparent capability of global dispersal across isolated coastal hypersaline environments (Clark et al., 2017), but the mode of dispersal is most likely via birds and wind, where they may be protected inside halite crystals (Clark et al., 2017; Kemp et al., 2018), especially given that many haloarchaea lyse in seawater (Torreblanca et al., 1986). No such vectors or protection would be available for transporting haloarchaea to the deep sea (though our understanding of dispersal mechanisms is limited). Dispersal of other DHAB-specific novel groups may be facilitated by overlying seawater. Haloclines do not represent an absolute barrier for penetration by motile microbes in the micrometre range (Doostmohammadi et al., 2012), but any DHAB-adapted microbe would presumably have to be actively moving while in the deep-sea water (or induced to reactivate from a dormant state 
upon reaching the halocline), and then able to overcome the rapid increase in viscosity and salinity as it returns to its preferred habitat. Nevertheless, to date, DHAB-specific taxa have not been detected in seawater.

An alternative explanation for this apparent paradox is microbes from these groups could be trapped in the salt crystals and/or brine inclusions, present in the possibly linked salt deposits under the Red Sea and Eastern Mediterranean, and released during the formation of the brines where they would thrive (Antunes et al., 2011d). Such long-term preservation and continued viability of microbes in ancient salt deposits is in line with several previous studies (e.g. Grant et al., 1998; McGenity et al., 2000; Mormile et al., 2003). Indeed, evidence is mounting in support of survival over millions of years (Røy et al., 2012), specifically in halite (McGenity et al., 2000; Schubert et al., 2010; Gramain et al., 2011; Jaakkola et al., 2016), and the interconnection between the geosphere and the biosphere, specifically in the context of the DHABs (biosphere) and the Messinian evaporites (geosphere) was discussed by McGenity et al. (2008). Collection and analysis of sediment cores of the evaporite layers would allow us to confirm the presence of such microbial groups and help clarify the process involved in the microbial colonization of the DHABs. Such studies would be very relevant for the future exploration of the icy moons of the outer Solar System.

An equally relevant and under-studied aspect regarding long-term preservation is the effect of such brines in the stability of bio-molecules. Previous reports pointed to the preserving effects of samples from the DHABs of the Mediterranean on DNA (Borin et al., 2008). One should note that this preservation would be affected by the type of salts present in the brine. In this regard, one particularly interesting location is the $\mathrm{MgCl}_{2}-$ saturated Discovery lake. Chaotropic $\mathrm{MgCl}_{2}$ destabilises macromolecules and would therefore significantly restrict any microbial/enzyme activity (Hallsworth et al., 2007). Therefore, Discovery DHAB, together with the other known $\mathrm{MgCl}_{2}$-rich brines, Lake Kryos and Hephaestus, would provide excellent locations for preserving biomolecules (Hallsworth et al., 2007; Sass et al., 2008).

The wide-range of chemical conditions present in the DHABs provide an ideal testing ground for looking into the effects of brine on microbes and bio-molecules, which would be easily linked to the astrobiological study of biosignatures under high-salinity conditions and lead to technical improvements. As an example of such an improvement, the discussion on this brine-preserving effect and detrimental impact on the reliability of results obtained from standard molecular-based analysis led to a switch to alternative RNA-based approaches in several subsequent studies. 
Technology development and testing: Fine-scale sampling and laboratorial replication of complex environments

One of the major benefits of working with terrestrial analogues is the opportunity to use such sites as a basis for developing, testing and finetuning different technologies and equipment in preparation for future space missions. Relevant examples of this approach include e.g. the use of Boulby mine in the MINAR- Mining and Analogue Research project (e.g. Payler et al., 2017; Cockell et al., 2018) or the current testing of prototype ice-melting probes in glaciers and regions with ice-sheets across the globe (e.g. Dachwald et al., 2014; Funke and Horneck, 2018). The exploration of deep-sea terrestrial locations and access to water bodies below thick ice layers are seen as vital for the future exploration of Mars and the icy moons of the outer Solar System so such inputs are an invaluable source of information.

The complex nature of DHABs and the drastic transitions observed at their brine-seawater interfaces also provide remarkable technical challenges that are relevant for Astrobiology. We believe that they also provide unique opportunities and ideal settings to develop and study new equipment for fine-scale sampling which would be relevant for exploring equivalent settings in the oceans of the icy moons of the Outer Solar System. The development of MODUS (Mobile Docker for Underwater Sciences), a Remotely Operated Vehicle designed to improve precision of sampling technologies and facilitate finer-scale sampling in such challenging environments was tested in situ in the DHABs of the Mediterranean (Malinverno et al., 2006) and was seen as a very relevant advance. The attempt to deploy the recently developed Microbial Sampler-Submersible Incubation Device (MS-SID) at the brine-seawater interface of Urania DHAB is also a welcome advance, notwithstanding the technical issues that affected its use (Pachiadaki et al., 2016). Despite these improvements, there is a clear need for further technical developments and improvements in this field.

Another technical issue to keep in mind is our limited capability to successfully replicate gradient-rich environments in the lab, a bottleneck which significantly hampers research in this field. Recent advances making use of gel-stabilised gradient plates (More et al., submitted) or the use of simulation chambers (e.g. Herschy et al., 2014) for the simulation of chemical gradients in liquid media, should help to fill this technical gap and are welcome additions to our current range of tools.

\section{Acknowledgements}

AA is funded by the Science and Technology Development Fund, Macau SAR. TJM acknowledges support from the European Cooperation in Science and Technology (COST) Action CA15103, "Uncovering the Mediterranean Salt Giant (MEDSALT)". KOF acknowledges support from the Science Technology Facilities Council, UK 


\section{References}

Abdallah, R.Z., Adel, M., Ouf, A., Sayed, A., Ghazy, M.A., Alam, I., Essack, M., Lafi, F.F., Bajic, V.B., El-Dorry, H., and Siam, R. (2014). Aerobic methanotrophic communities at the Red Sea brine-seawater interface. Front. Microbiol. 5, 487. https://doi.org/10.3389/fmicb.2014.00487

Albuquerque, L., Taborda, M., La Cono, V., Yakimov, M., and da Costa, M.S. (2012). Natrinema salaciae sp. nov., a halophilic archaeon isolated from the deep, hypersaline anoxic Lake Medee in the Eastern Mediterranean Sea. Syst. Appl. Microbiol. 35, 368-373. https://doi.org/ 10.1016/j.syapm.2012.06.005

Antunes, A. (2017). Extreme Red Sea: life in the deep-sea anoxic brine lakes. In Human Interaction with the Environment in the Red Sea, D.A. Agius, E. Khalil, E. Scerri, and A. Williams, eds. (Leiden, Netherlands: Brill), pp. 30-47. https://doi.org/10.1163/9789004330825_004

Antunes, A., Eder, W., Fareleira, P., Santos, H., and Huber, R. (2003). Salinisphaera shabanensis gen. nov., sp. nov., a novel, moderately halophilic bacterium from the brine-seawater interface of the Shaban Deep, Red Sea. Extremophiles 7, 29-34. https://doi.org/10.1128/JB. 05459-11

Antunes, A., França, L., Rainey, F.A., Huber, R., Nobre, M.F., Edwards, K.J., and da Costa, M.S. (2007). Marinobacter salsuginis sp. nov., isolated from the brine-seawater interface of the Shaban Deep, Red Sea. Int. J. Syst. Evol. Microbiol. 57, 1035-1040. https://doi.org/10.1099/ ijs.0.64862-0

Antunes, A., Rainey, F.A., Wanner, G., Taborda, M., Pätzold, J., Nobre, M.F., da Costa, M.S., and Huber, R. (2008a). A new lineage of halophilic, wall-less, contractile bacteria from a brine-filled deep of the Red Sea. J. Bacteriol. 190, 3580-3587. https://dx.doi.org/10.1128\%2FJB.01860-07

Antunes, A., Taborda, M., Huber, R., Moissl, C., Nobre, M.F., and da Costa, M.S. (2008b). Halorhabdus tiamatea sp. nov., a non-pigmented, extremely halophilic archaeon from a deep-sea, hypersaline anoxic basin of the Red Sea, and emended description of the genus Halorhabdus. Int. J. Syst. Evol. Microbiol. 58, 215-220. https://dx.doi.org/10.1099/ijs. 0.65316-0

Antunes, A., Alam, I., Bajic, V.B., and Stingl, U. (2011a). Genome sequence of Haloplasma contractile, an unusual contractile bacterium from a deepsea anoxic brine lake. J Bacteriol. 193, 4551-4552. https://doi.org/ 10.1128/JB.05461-11

Antunes, A., Alam, I., Bajic, V.B., and Stingl, U. (2011b). Genome sequence of Halorhabdus tiamatea, the first archaeon isolated from a deep-sea anoxic brine lake. J. Bacteriol. 193, 4553-4554. https://doi.org/10.1128/ JB.05462-11

Antunes, A., Alam, I., Bajic, V.B., and Stingl, U. (2011c). Genome sequence of Salinisphaera shabanensis, a gammaproteobacterium from the harsh, variable environment of the brine-seawater interface of the Shaban Deep 
in the Red Sea. J. Bacteriol. 193, 4555-4556. https://doi.org/10.1128/JB. 05459-11

Antunes, A., Ngugi, D.K., and Stingl, U. (2011d). Microbiology of the Red Sea (and other) deep-sea anoxic brine lakes. Environ. Microbiol. Rep. 3(4), 416-433. https://doi.org/10.1111/j.1758-2229.2011.00264.x

Antunes, A., Alam, I., Simões, M.F., Daniels, C., Ferreira, A.J., Siam, R., ElDorry, H., and Bajic, V.B. (2015). First insights into the viral communities of the deep-sea anoxic brines of the Red Sea. Genomics Proteomics Bioinformatics 13, 304-309. https://doi.org/10.1016/j.gpb.2015.06.004

Antunes, A., Kaartvedt, S., and Schmidt, M. (2019). Geochemistry and life at the interfaces of brine-filled deeps in the Red Sea. In Oceanographic and Biological Aspects of the Red Sea, N.M.A. Rasul and I.C.F. Stewart, eds. (Cham, Switzerland: Springer Nature), pp. 185-194.

Backer, H. and Schoell, M. (1972). New deeps with brines and metalliferous sediments in the Red Sea. Nat. Phys. Sci. 240, 153-158. https://doi.org/10.1038/physci240153a0

Barge, L.M., and White, L.M. (2017). Experimentally Testing Hydrothermal Vent Origin of Life on Enceladus and Other Icy/Ocean Worlds. Astrobiology 17, 820-833. https://doi.org/10.1089/ast.2016.1633

Billings, S.E., and Kattenhorn, S.A. (2005). The great thickness debate: Ice shell thickness models for Europa and comparisons with estimates based on flexure at ridges. Icarus 177, 397-412. https://doi.org/10.1016/ j.icarus.2005.03.013

Blum, N. and Puchelt, H. (1991). Sedimentary-hosted polymetallic massive sulfide deposits of the Kebrit and Shaban Deeps, Red Sea. Miner. Depos. 26, 217-227. https://doi.org/10.1007/BF00209261

Borin, S., Crotti, E., Mapelli, F., Tamagnini, I., Corselli, C. and Daffonchio, D. (2008). DNA is preserved and maintains transforming potential after contact with brines of the deep anoxic hypersaline lakes of the Eastern Mediterranean Sea. Saline Systems. 4, 10. https://doi.org/ 10.1186/1746-1448-4-10

Borin, S., Brusetti, L., Mapelli, F., D'Auria, G., Brusa, T., Marzorati, M., Rizzi, A., Yakimov, M., Marty, D., De Lange, G.J., Van der Wielen, Bolhuis, P.H., McGenity, T.J., Polymenakou, P.N., Malinverno, E., Giuliano, L., Corselli, C. and Daffonchio, D. (2009). Sulfur cycling and methanogenesis primarily drive microbial colonization of the highly sulfidic Urania deep hypersaline basin. Proc. Natl. Acad. Sci. U. S. A. 106, 9151-9156. https://doi.org/10.1073/pnas.0811984106

Borin, S., Mapelli, F., Rolli, E., Song, B., Tobias, C., Schmid, M.C., De Lange, G.J., Reichart, G.J., Schouten, S., Jetten, M. and Daffonchio, D. (2013). Anammox bacterial populations in deep marine hypersaline gradient systems. Extremophiles 17, 289-299. https://doi.org/10.1007/ s00792-013-0516-x

Borrel, G., Parisot, N., Harris, H.M.B., Peyretaillade, E., Gaci, N., Tottey, W., Bardot, O., Raymann, K., Gribaldo, S., Peyret, P., O'Toole, P.W., and Brugère, J.-F. (2014). Comparative genomics highlights the unique biology of Methanomassiliicoccales, a Thermoplasmatales-related 
seventh order of methanogenic archaea that encodes pyrrolysine. BMC genomics. 15(1), 679. https://doi.org/10.1186/1471-2164-15-679

Bougouffa, S., Yang, J.K., Lee, O.O., Wang, Y., Batang, Z., Al-Suwailem, A., and Qian, P.Y. (2013). Distinctive microbial community structure in highly stratified deep-sea brine water columns. Appl. Environ. Microbiol. 79, 3425-3437. http://dx.doi.org/10.1128/AEM.00254-13

Brown, R.H., Clark, R.N., Buratti, B.J., Cruikshank, D.P., Barnes, J.W., Mastrapa, R.M.E., Bauer, J., Newman, S., Momary, T., Baines, K.H., Bellucci, G., Capaccioni, F., Cerroni, P., Combes, M., Coradini, A., Drossart, P., Formisano, V., Jaumann, R., Langevin, Y., Matson, D.L., Mccord, T.B., Nelson, R.M., Nicholson, P.D., Sicardy, B., and Sotin, C. (2006). Composition and physical properties of Enceladus' surface. Science. 311, 1425-1428. http://dx.doi.org/10.1126/science.1121031

Bruneau, L., Jerlov, N.G., and Koczy, F.F. (1953). Physical and chemical methods (+ Appendix), In Reports of the Swedish deep-sea expedition, vol. III. Physics and chemistry, no. 4, N.G. Jerlov, ed. (Goteborg, Sweden: Elanders), pp. 99-112.

Brusa, T., Borin, S., Ferrari, F., Sorlini, C., Corselli, C., and Daffonchio, D. (2001). Aromatic hydrocarbon degradation patterns and catechol 2,3dioxygenase genes in microbial cultures from deep anoxic hypersaline lakes in the eastern Mediterranean sea. Microbiol. Res. 156, 49-57.

Cadek, O., Tobie, G., Van Hoolst, T., Masse, M., Choblet, G., Lefevre, A., Mitri, G., Baland, R.M., Behounkova, M., Bourgeois, O., and Trinh, A. (2016). Enceladus's internal ocean and ice shell constrained from Cassini gravity, shape, and libration data. Geophys. Res. Lett. 43, 5653-5660. https://doi.org/10.1002/2016GL068634

Camerlenghi, A. (1990) Anoxic basins of the eastern Mediterranean: geological framework. Mar. Chem. 31, 1-19. https://doi.org/ 10.1016/0304-4203(90)90028-B

Carlson, R.W., Calvin, W.M., Dalton III, J.B., Hansen, G.B., Hudson, R.L., Johnson, R.E., Mccord, T.B., and Moore, M.H. (2009). Europa's surface composition. In Europa, R.T. Pappalardo, W.B. McKinnon, and K.K. Khurana, eds. (Tucson, AZ, USA: University of Arizona Press), pp. 283-327.

Carr, M.H., Belton, M.J.S., Chapman, C.R., Davies, A.S., Geissler, P., Greenberg, R., Mcewen, A.S., Tufts, B.R., Greeley, R., Sullivan, R., Head, J.W., Pappalardo, R.T., Klaasen, K.P., Johnson, T.V., Kaufman, J., Senske, D., Moore, J., Neukum, G., Schubert, G., Burns, J.A., Thomas, P., and Veverka, J. (1998). Evidence for a subsurface ocean on Europa. Nature. 391, 363-365. https://doi.org/10.1038/34857

Cita, M.B., Kastens, K.A., McCoy, F.W., Aghib, F., Cambi, A., Camerlenghi, A., Corselli, C., Erba, E., Giambastiani, M., Herbert, T., Leoni, C., Malinverno, P., Nosetto, A., and Parisi, E. (1985). Gypsum precipitation from cold brines in an anoxic basin in the eastern Mediterranean. Nature. 314, 152-154. https://doi.org/10.1038/314152a0 
Cita, M.B. (2006). Exhumation of Messinian evaporites in the deep-sea and creation of deep anoxic brine-filled collapsed basins. Sediment. Geol. 188, 357-378. https://doi.org/10.1016/j.sedgeo.2006.03.013

Clark, D.R., Mathieu, M., Mourot, L., Dufossé, L., Underwood, G.J.C., Dumbrell, A.J., and McGenity, T.J. (2017). Biogeography at the limits of life: Do extremophilic microbial communities show biogeographic regionalisation? Glob. Ecol. Biogeogr. 26, 1435-1446. https://doi.org/ 10.1111/geb.12670

Cochran, J.R., Martinez, F., Steckler, M.S., and Hobart, M.A. (1986). Conrad Deep: A new Northern Red Sea Deep. Origin and implications for continental rifting. Earth Planet. Sci. Lett. 78, 18-32. https://doi.org/ 10.1016/0012-821X(86)90169-X

Cockell, C.S., Holt, J., Campbell, J., Groseman, H., Josset, J.L., Bontognali, T.R., Phelps, A., Hakobyan, L., Kuretn, L., Beattie, A., Blank, J., Bonaccorsi, R., McKay, C., Shirvastava, A., Stoker, C., Willson, D., McLaughlin, S., Payler, S., Stevens, A., Wadsworth, J., Bessone, L., Maurer, M., Sauro, F., Martin-Torres, J., Zorzano, M.P., Bhardwaj, A., Soria-Salinas, A., Mathanlal, T., Nazarious, M.I., Ramachandran, A.V., Vaishampayan, P., Guan, L., Perl, S.M., Telling, J., Boothroyd, I.M., Tyson, O., Realff, J., Rowbottom, J., Lauernt. B., Gunn, M., Shah, S., Singh, S., Paling, S., Edwards, T., Yeoman, L., Meehan, E., Toth, C., Scovell, P., and Suckling, B. (2018). Subsurface scientific exploration of extraterrestrial environments (MINAR 5): analogue science, technology and education in the Boulby Mine, UK. Int. J. Astrobiol. 1-26. https:// doi.org/10.1017/S1473550418000186

Corinaldesi, C., Tangherlini, M., Luna, G.M., and Dell'Anno, A. (2014). Extracellular DNA can preserve the genetic signatures of present and past viral infection events in deep hypersaline anoxic basins. Proc. R. Soc. Lond. B: Biol. Sci. 281, 20133299. https://doi.org/10.1098/rspb. 2013.3299

Dachwald, B., Mikucki, J., Tulaczyk, S., Digel, I., Espe, C., Feldmann, M., Francke, G., Kowalski, J., and Xu, C. (2014). IceMole: a maneuverable probe for clean in situ analysis and sampling of subsurface ice and subglacial aquatic ecosystems. Ann. Glaciol. 55, 14-22.

https://doi.org/10.3189/2014AoG65A004

Daffonchio, D., Borin, S., Brusa, T., Brusetti, L., van der Wielen, P.W.J.J., Bolhuis, H., D'Auria, G., Yakimov, M., Giuliano, L., Tamburini, C., Marty, D., McGenity, T.J., Hallsworth, J.E., Sass, A.M., Timmis, K.N., Tselepides, A., de Lange, G.J., Huebner, A., Thomson, J., Varnavas, S.P., Gasparoni, F., Gerber, H.W., Malinverno, E., Corselli, C., and Biodeep Scientific Party (2006). Stratified prokaryote network in the oxic- anoxic transition of a deep-sea halocline. Nature 440, 203-207. https://doi.org/10.1038/ nature 04418

Danovaro, R., Corinaldesi, C., Dell'Anno, A., Fabiano, M., and Corselli, C. (2005). Viruses, prokaryotes and DNA in the sediments of a deephypersaline anoxic basin (DHAB) of the Mediterranean Sea. Environ. Microbiol. 7, 586-592. https://doi.org/10.1111/j.1462-2920.2005.00727.x 
Danovaro, R., Dell'Anno, A., Pusceddu, A., Gambi, C., Heiner, I., and Kristensen, R.M. (2010). The first metazoa living in permanently anoxic conditions. BMC Biol. 8, 30. https://doi.org/10.1186/1741-7007-8-30

Danovaro, R., Gambi, C., Dell'Anno, A., Corinaldesi, C., Pusceddu, A., Neves, R.C., and Kristensen, R.M. (2016). The challenge of proving the existence of metazoan life in permanently anoxic deep-sea sediments. BMC Biol. 14, 43. https://doi.org/10.1186/s12915-016-0263-4

De Lange, G.J., Catalano, G., Klinkhammer, G.P., and Luther III, G.W. (1990a). The interface between oxic seawater and the anoxic Bannock brine; its sharpness and the consequences for the redox-related cycling of $\mathrm{Mn}$ and $\mathrm{Ba}$. Mar. Chem. 31, 205-217. https://doi.org/ 10.1016/0304-4203(90)90039-F

De Lange, G.J., Middelburg, J.J., Van der Weijden, C.H., Catalano, G., Luther lii, G.W., Hydes, D.J., Woittiez, J.R.W., and Klinkhammer, G.P. (1990b) Composition of anoxic hypersaline brines in the Tyro and Bannock Basins, Eastern Mediterranean. Mar. Chem. 31, 63-88. https:// doi.org/10.1016/0304-4203(90)90031-7

Doostmohammadi, A., Stocker, R., and Ardekani, A.M. (2012). LowReynolds-number swimming at pycnoclines. Proc. Natl. Acad. Sci. USA 109, 3856-3861. https://doi.org/10.1073/pnas.1116210109

Eder, W., Ludwig, W., and Huber, R. (1999). Novel 16S rRNA gene sequences retrieved from highly saline brine sediments of Kebrit Deep, Red Sea. Arch. Microbiol. 172, 213-218. https://doi.org/10.1007/ s0020300507

Eder, W., Jahnke, L. L., Schmidt, M., and Huber, R. (2001). Microbial diversity of the brine-seawater interface of the Kebrit Deep, Red Sea, studied via $16 S$ rRNA gene sequences and cultivation methods. Appl. Environ. Microbiol. 67, 3077-3085. https://doi.org/10.1128/AEM. 67.7.3077-3085.2001

Eder, W., Schmidt, M., Koch, M., Garbe-Schönberg, D., and Huber, R. (2002). Prokaryotic phylogenetic diversity and corresponding geochemical data of the brine-seawater interface of the Shaban Deep, Red Sea. Environ. Microbiol. 4, 758-763. https://doi.org/10.1046/j. 1462-2920.2002.00351.x

Edgcomb, V.P., Pachiadaki, M.G., Mara, P., Kormas, K.A., Leadbetter, E.R. and Bernhard, J.M. (2016) Gene expression profiling of microbial activities and interactions in sediments under haloclines of $E$. Mediterranean deep hypersaline anoxic basins. ISME J. 10, 2643-2657. https://doi.org/10.1038/ismej.2016.58

Emery, J.P., Burr, D.M., Cruikshank, D.P., Brown, R.H., and Dalton, J.B. (2005). Near-infrared (0.8-4.0 $\mu \mathrm{m})$ spectroscopy of Mimas, Enceladus, Tethys, and Rhea. Astron. Astrophys. 435, 353-362. https://doi.org/ 10.1051/0004-6361:20042482

Ehrhardt, A., Hübscher, C., and Gajewski, D. (2005). Conrad Deep, Northern Red Sea: Development of an early stage ocean deep within the axial depression. Tectonophysics, 411(1-4), 19-40. https://doi.org/ 10.1016/j.tecto.2005.08.011 
Elsenousy, A., Vance, S., Bills, B.G., and Goodman, J. (2015). Modeling Heat and Salt Transfer at Europa's Ice-Ocean Interface. In Lunar and Planetary Science Conference vol. 46 (The Woodlands,TX, USA: Lunar and Planetary Institute), p. 1676.

Faber, E., Botz, R., Poggenburg, J., Schmidt, M., Stoffers, P., and Hartmann, M. (1998). Methane in Red Sea brines. Org. Geochem. 29, 363-379. https://doi.org/10.1016/S0146-6380(98)00155-7

Ferrer, M., Golyshina, O.V., Chemikova, T.N., Khachane, A.N., dos Santos V.A.P.M., Yakimov, M.M., Timmis, K.N., and Golyshin, P.N. (2005). Microbial enzymes mined from the Urania deep-sea hypersaline anoxic basin. Chem. Biol. 12, 895-904. https://doi.org/10.1016/j.chembiol. 2005.05.020

Fiala, G., Woese, C.R., Langworthy, T.A., and Stetter, K.O. (1990). Flexistipes sinusarabici, a novel genus and species of eubacteria occurring in the Atlantis II Deep brines of the Red Sea. Arch. Microbiol. 154, 120-126. https://doi.org/10.1007/BF00423320

Fox-Powell, M.G., Hallsworth, J.E., Cousins, C.R., and Cockell, C.S. (2016). lonic strength is a barrier to the habitability of Mars. Astrobiology 16, 427-442. https://doi.org/10.1089/ast.2015.1432

Funke, O. and Horneck, G. (2018). The Search for Signatures of Life and Habitability on Planets and Moons of Our Solar System. In Biological, Physical and Technical Basics of Cell Engineering, G. Artmann, A. Artmann, A. Zhubanova, and I. Digel, eds. (Singapore: Springer), pp. 457-481. https://doi.org/10.1007/978-981-10-7904-7_20

Garcia-Lopez, E., and Cid, C. (2017). Glaciers and Ice Sheets as Analog Environments of Potentially Habitable Icy Worlds. Front. Microbiol. 8, 1407. https://doi.org/10.3389/fmicb.2017.01407

Garrity, G.M., Holt, J.M., Huber, H., Stetter, K.O., Greene, A.C., Patel, B.K., Caccavo Jr., F., Allison, M.J., MacGregor, B.J., and Stahl, D.A. (2001). Phylum BIX. Deferribacteres phy. nov. In Bergey's Manual of Systematic Bacteriology vol. 1., D.R. Boone, R.W. Castenholz, and G.M., eds. (New York, NY, USA: Springer), pp. 465-47. https://doi.org/ 10.1007/978-0-387-21609-6_26

Geissler, P.E., Greenberg, R., Hoppa, G., Mcewen, A., Tufts, R., Phillips, C., Clark, B., Ockert-Bell, M., Helfenstein, P., Burns, J., Veverka, J., Sullivan, R., Greeley, R., Pappalardo, R.T., Head, J.W., Belton, M.J.S., and Denk, T. (1998). Evolution of lineaments on Europa: Clues from Galileo multispectral imaging observations. Icarus. 135, 107-126. https:// doi.org/10.1006/icar.1998.5980

Gleeson, D.F., Pappalardo, R.T., Anderson, M.S., Grasby, S.E., Mielke, R.E., Wright, K.E., and Templeton, A.S. (2012). Biosignature Detection at an Arctic Analog to Europa. Astrobiology. 12, 135-150. https://doi.org/ 10.1089/ast.2010.0579

Glein, C.R., Baross, J.A., and Waite Jr, J.H. (2015). The pH of Enceladus' ocean. Geochim. Cosmochim. Acta. 162, 202-219. https://doi.org/ 10.1016/j.gca.2015.04.017 
Glein, C.R., and Shock, E.L. (2010). Sodium chloride as a geophysical probe of a subsurface ocean on Enceladus. Geophys. Res. Lett. 37, L09204. https://doi.org/10.1029/2010GL042446

Gramain, A., Díaz, G.C., Demergasso, C., Lowenstein, T.K., and McGenity, T.J. (2011) Archaeal diversity along a subterranean salt core from the Salar Grande (Chile). Environ. Microbiol. 13, 2105-2121. https://doi.org/ 10.1111/j.1462-2920.2011.02435.x

Grant, W.D., Gemmell, R.T., and McGenity, T.J. (1998). Halobacteria: the evidence for longevity. Extremophiles. 2(3), 279-287.

Guan, Y., Hikmawan, T., Antunes, A., Ngugi, D., and Stingl, U. (2015). Diversity of methanogens and sulfate-reducing bacteria in the interfaces of five deep-sea anoxic brines of the Red Sea. Res. Microbiol. 166, 688-699. https://doi.org/10.1016/j.resmic.2015.07.002

Hallsworth, J.E., Yakimov, M.M., Golyshin, P.N., Gillion, J.L.M., D'Auria, G., de Lima Alves, F., La Cono, V., Genovese, M., McKew, B.A., Hayes, S.L., Harris, G., Giuliano, L., Timmis, K.N., and McGenity, T.J. (2007) Limits of life in $\mathrm{MgCl}_{2}$-containing environments: chaotropicity defines the window. Environ. Microbiol. 9, 801-813. https://doi.org/10.1111/j. 1462-2920.2006.01212.x

Han, L.J., and Showman, A.P. (2010). Coupled convection and tidal dissipation in Europa's ice shell. Icarus. 207, 834-844. https://doi.org/ 10.1016/j.icarus.2009.12.028

Hand, K.P., and Carlson, R.W. (2015). Europa's surface color suggests an ocean rich with sodium chloride. Geophys. Res. Lett. 42, 3174-3178. https://doi.org/10.1002/2015GL063559

Hand, K.P., Chyba, C.F., Priscu, J.C., Carlson, R.W., and Nealson, K.H. (2009). Astrobiology and the potential for life on Europa. In Europa, R.T. Pappalardo, W.B. McKinnon, and K.K. Khurana, eds. (Tucson, AZ, USA: University of Arizona Press), pp. 589-630.

Harrison, J.P., Gheeraert, N., Tsigelnitskiy, D., and Cockell, C.S. (2013). The limits for life under multiple extremes. Trends Microbiol. 21, 204-212. https://doi.org/10.1016/j.tim.2013.01.006

Heitzer, R.D. and Ottow, J.C.G. (1976). New denitrifying bacteria isolated from Red Sea sediments. Mar. Biol. 37, 1-10. https://doi.org/10.1007/ BF00386773

Hendrix, A.R., Hurford, T.A., Barge, L.M., Bland, M.T., Bowman, J.S., Brinckerhoff, W., Buratti, B.J., Cable, M.L., Castillo-Rogez, J., Collins, G.C., and Diniega, S. (2019). The NASA Roadmap to Ocean Worlds. Astrobiology 19(1), 1-27. https://doi.org/10.1089/ast.2018.1955

Herschy, B., Whicher, A., Camprubi, E., Watson, C., Dartnell, L., Ward, J., Evans, J.R.G. and Lane, N. (2014). An origin-of-life reactor to simulate alkaline hydrothermal vents. J. Mol. Evol. 79, 213-227. https://doi.org/ 10.1007/s00239-014-9658-4

Hovland, M., Rueslåtten, H.G., and Johnsen, H.K. (2018). Large salt accumulations as a consequence of hydrothermal processes associated with 'Wilson cycles': A review Part 1: Towards a new understanding. Mar. Pet. Geol. 92, 128-148. https://doi.org/10.1016/j.marpetgeo.2017.12.029 
Howett, C.J.A., Spencer, J.R., Pearl, J., and Segura, M. (2010). Thermal inertia and bolometric Bond albedo values for Mimas, Enceladus, Tethys, Dione, Rhea and lapetus as derived from Cassini/CIRS measurements. Icarus. 206, 573-593. https://doi.org/10.1016/j.icarus.2009.07.016

Hsu, H.W., Postberg, F., Sekine, Y., Shibuya, T., Kempf, S., Horanyi, M., Juhasz, A., Altobelli, N., Suzuki, K., Masaki, Y., Kuwatani, T., Tachibana, S., Sirono, S., Moragas-Klostermeyer, G., and Srama, R. (2015). Ongoing hydrothermal activities within Enceladus. Nature. 519, 207. https://doi.org/10.1038/nature14262

less, L., Stevenson, D.J., Parisi, M., Hemingway, D., Jacobson, R.A., Lunine, J.I., Nimmo, F., Armstrong, J.W., Asmar, S.W., Ducci, M., and Tortora, P. (2014). The Gravity Field and Interior Structure of Enceladus. Science. 344, 78-80. https://doi.org/10.1126/science.1250551

Jaakkola, S.T., Ravantti, J.J., Oksanen, H.M., and Bamford, D.H. (2016). Buried alive: Microbes from ancient halite. Trends Microbiol. 24, 148-159. https://doi.org/10.1016/j.tim.2015.12.002

Jia, X.Z., Kivelson, M.G., Khurana, K.K., and Kurth, W.S. (2018). Evidence of a plume on Europa from Galileo magnetic and plasma wave signatures. Nat. Astron. 2, 459-464. https://doi.org/10.1038/ s41550-018-0450-z

Jongsma, D., Fortuin, A.R., Huson, W., Troelstra, S.R., Klaver, G.T., Peters, J.M., van Harten, D., de Lange, G.J., and ten Haven, L. (1983). Discovery of an anoxic basin within the Strabo trench, eastern Mediterranean. Nature. 305, 795-797. https://doi.org/10.1038/305795a0

Kaartvedt, S., Antunes, A., Røstad, A., Klevjer, T.A., and Vestheim, H. (2016). Zooplankton at deep Red Sea brine pools. J. Plankton Res. 38, 679-684. https://doi.org/10.1093/plankt/fbw013

Kargel, J.S., Kaye, J.Z., Head, J.W., Marion, G.M., Sassen, R., Crowley, J.K., Prieto Ballesteros, O., Grant, S.A., and Hogenboom, D.L. (2000). Europa's crust and ocean: Origin, composition, and the prospects for life. Icarus. 148, 226-265. https://doi.org/10.1006/icar.2000.6471

Kaye, J. Z. and Baross, J. A. (2004). Synchronous effects of temperature, hydrostatic pressure, and salinity on growth, phospholipid profiles, and protein patterns of four Halomonas species isolated from deep-sea hydrothermal-vent and sea surface environments. Appl. Environ. Microbiol. 70(10), 6220-6229. https://doi.org/10.1128/AEM. 70.10.6220-6229.2004

Kemp, B.L., Tabish, E.M., Wolford, A.J., Jones, D.L., Butler, J.K., and Baxter, B.K. (2018) The Biogeography of Great Salt Lake Halophilic Archaea: Testing the Hypothesis of Avian Mechanical Carriers. Diversity. 10, 124. https://doi.org/10.3390/d10040124

Khurana, K.K., Kivelson, M.G., Stevenson, D.J., Schubert, G., Russell, C.T., Walker, R.J., and Polanskey, C. (1998). Induced magnetic fields as evidence for subsurface oceans in Europa and Callisto. Nature. 395, 777-780. https://doi.org/10.1038/27394 
Kivelson, M.G., Khurana, K.K., and Volwerk, M. (2002). The permanent and inductive magnetic moments of Ganymede. Icarus. 157, 507-522. https://doi.org/10.1006/icar.2002.6834

Kivelson, M.G., Khurana, K.K., Russell, C.T., Volwerk, M., Walker, R.J., and Zimmer, C. (2000). Galileo magnetometer measurements: A stronger case for a subsurface ocean at Europa. Science. 289, 1340-1343. https:// doi.org/10.1126/science.289.5483.1340

La Cono, V., Bortoluzzi, G., Messina, E., La Spada, G., Smedile, F., Giuliano, L., Borghini, M., Stumpp, C., Schmitt-Kopplin, P., Harir, M., O'Neill, W.K., Hallsworth, J.E., and Yakimov M.M. (2019). The discovery of Lake Hephaestus, the youngest athalassohaline deep-sea formation on Earth. Sci. Rep. 9, 1679. https://doi.org/10.1038/s41598-018-38444-z

La Cono, V., Arcadi, E., and La Spada, G. (2015). A three-component microbial consortium from deep-sea salt-saturated anoxic Lake Thetis links anaerobic glycine betaine degradation with methanogenesis. Microorganisms. 3, 500-517. https://doi.org/10.3390/microorganisms3030500

La Cono, V., Smedile, F., Bortoluzzi, G., Arcadi, E., Maimone, G., Messina, E., Borghini, M., Oliveri, E., Mazzola, S., L'haridon, S., Toffin, L., Genovese, L., Ferrer, M., Giuliano, L., Golyshin, P.N., and Yakimov, M.M. (2011). Unveiling microbial life in new deep-sea hypersaline Lake Thetis. Part I: prokaryotes and environmental settings. Environ. Microbiol. 13, 2250-2268. https://doi.org/10.1111/j.1462-2920.2011.02478.x

Lima de Alves, F., Stevenson, A., Baxter, E., Gillion, J.L.M., Hejazi, F., Hayes, S., Morrison, I.E.G., Prior, B.A., McGenity, T.J., Rangel, D.E.N., Magan, N., Timmis, K.N., and Hallsworth, J.E. (2015). Concomitant osmotic and chaotropicity-induced stresses in Aspergillus wentii: compatible solutes determine the biotic window. Curr. Genet. 61, 457-477. https://doi.org/10.1007/s00294-015-0496-8

Lloyd, K.G., Lapham, L., and Teske, A. (2006). An anaerobic methaneoxidizing community of ANME-1b Archaea in hypersaline Gulf of Mexico sediments. Appl. Environ. Microbiol. 72, 7218-7230. https://doi.org/ 10.1128/AEM.00886-06

Lunine, J.I. (2017). Ocean worlds exploration. Acta Astronaut. 131, 123-130. https://doi.org/10.1016/j.actaastro.2016.11.017

Malinverno, E., Gasparoni, F., Gerber, H.W., and Corselli, C. (2006). The exploration of Eastern Mediterranean deep hypersaline anoxic basins with MODUS: a significant example of technology spin-off from the GEOSTAR program. Ann. Geophys. 49(2-3), 729-37. https://doi.org/ 10.4401/ag-3129

Marion, G.M., Fritsen, C.H., Eicken, H., Payne, M.C. (2003). The search for life on Europa: limiting environmental factors, potential habitats, and earth analogues. Astrobiology. 3, 785-811. https://doi.org/ 10.1089/153110703322736105

Martins, Z., Cottin, H., Kotler, J.M., Carrasco, N., Cockell, C.S., Noetzel, R.D., Demets, R., De Vera, J.P., D'hendecourt, L., Ehrenfreund, P., Elsaesser, A., Foing, B., Onofri, S., Quinn, R., Rabbow, E., Rettberg, P., Ricco, A.J., Slenzka, K., Stalport, F., Ten Kate, I.L., Van Loon, J., and 
Westall, F. (2017). Earth as a Tool for Astrobiology-A European Perspective. Space Sci. Rev. 209, 43-81. https://doi.org/10.1007/ s11214-017-0369-1

McGenity, T.J., Gemmell, R.T., Grant, W.D., and Stan-Lotter, H. (2000). Origins of halophilic microorganisms in ancient salt deposits. Environ Microbiol 2, 243-250. https://doi.org/10.1046/j.1462-2920.2000.00105.x

McGenity, T.J., Hallsworth, J.E., and Timmis, K.N. (2008). Connectivity between 'ancient' and 'modern' hypersaline environments, and the salinity limits of life. CIESM 2008, The Messinian Salinity Crisis from mega-deposits to microbiology - A consensus report. No. 33. In CIESM Workshop Monographs, F. Briand, ed. (Monaco: CIESM), pp. 115-120.

McGenity, T.J., and Sorokin, D. (2018). Methanogens and methanogenesis in hypersaline environments. In Handbook of Hydrocarbon and Lipid Microbiology: Biogenesis of Hydrocarbons $2^{\text {nd }}$ Edition, A. Stams and D. Sousa, ed. (Berlin, Germany: Springer), pp. 665-680. https://doi.org/ 10.1007/978-3-319-53114-4_12-1

MEDRIFF Consortium. (1995). Three brine lakes discovered in the seafloor of the Eastern Mediterranean. EOS Trans. AGU. 76 (32), 313-318. https://doi.org/10.1029/95EO00189

Merlino, G., Barozzi, A., Michoud, G., Ngugi, D.K., and Daffonchio, D. (2018). Microbial ecology of deep-sea hypersaline anoxic basins. FEMS Microbiol. Ecol. 94, fiy085. https://doi.org/10.1093/femsec/fiy085

Messina, E., Sorokin, D.Y., Kublanov, I.V., Toshchakov, S., Lopatina, A., Arcadi, E., Smedile, F., La Spada, G., La Cono, V., and Yakimov, M.M. (2016). Complete genome sequence of 'Halanaeroarchaeum sulfurireducens' M27-SA2, a sulfur-reducing and acetate-oxidizing haloarchaeon from the deep-sea hypersaline anoxic lake Medee. Stand. Genomic Sci. 11(1), 35. https://doi.org/10.1186/s40793-016-0155-9

Michaelis, W.A., Jenisch, A., and Richnow, H.H. (1990). Hydrothermal petroleum generation in Red Sea sediments from the Kebrit and Shaban Deeps. Appl. Geochem. 5, 103-114. https://doi.org/10.1016/0883-2927(90)90041-3

Miller, A.R. (1964). Highest salinity in the world ocean? Nature. 203, 590-591. https://doi.org/10.1038/203590a0

More-Mutch, P., Huber, R., and Antunes, A. (2020). Gel-stabilized gradient plates: a new cultivation approach for the laboratorial recreation of naturally-occurring interfaces. Front. Microbiol. (submitted).

Mormile, M.R., Biesen, M.A., Gutierrez, M.C., Ventosa, A., Pavlovich, J.B., Onstott, T.C., and Fredrickson, J.K. (2003). Isolation of Halobacterium salinarum retrieved directly from halite brine inclusions. Environ. Microbiol. 5, 1094-1102.

Mwirichia, R., Alam, I., Rashid, M., Vinu, M., Ba-Alawi, W., Kamau, A.A., Ngugi, D.K., Göker, M., Klenk, H.P., Bajic, V., and Stingl, U. (2016). Metabolic traits of an uncultured archaeal lineage-MSBL1-from brine pools of the Red Sea. Sci. Rep. 6, 19181. https://doi.org/10.1038/ srep19181

Ngugi, D.K., and Stingl, U. (2018). High-quality draft single-cell genome sequence belonging to the archaeal candidate division SA1, isolated 
from Nereus Deep in the Red Sea. Genome Announc. 6(19), e00383-18. https://doi.org/10.1128/genomeA.00383-18.

Ngugi, D.K., Blom, J., Alam, I., Rashid, M., Ba-Alawi, W., Zhang, G., Hikmawan, T., Guan, Y., Antunes, A., Siam, R., El Dorry, H., Bajic, V., and Stingl, U. (2015). Comparative genomics reveals adaptations of a halotolerant thaumarchaeon in the interfaces of brine pools in the Red Sea. ISME J. 9, 396-411. https://doi.org/10.1038/ismej.2014.137

Ngugi, D.K., Blom, J., Stepanauskas, R., and Stingl, U. (2016). Diversification and niche adaptations of Nitrospina-like bacteria in the polyextreme interfaces of Red Sea brines. ISME J. 10, 1383. https:// doi.org/10.1038/ismej.2015.214

Nigro, L.M., Hyde, A. S., MacGregor, B.J., and Teske, A. (2016). Phylogeography, salinity adaptations and metabolic potential of the candidate division KB1 bacteria based on a partial single cell genome. Front. Microbiol. 7, 1266. https://doi.org/10.3389/fmicb.2016.01266

Nimmo, F., Spencer, J.R., Pappalardo, R.T., and Mullen, M.E. (2007). Shear heating as the origin of the plumes and heat flux on Enceladus. Nature. 447, 289-291. https://doi.org/10.1038/nature05783

Oliver, P. G., Vestheim, H., Antunes, A., and Kaartvedt, S. (2015). Systematics, functional morphology and distribution of a bivalve (Apachecorbula muriatica gen. et sp. nov.) from the rim of the 'Valdivia Deep' brine pool in the Red Sea. J. Mar. Biol. Assoc. U. K. 95, 523-535. https://doi.org/10.1017/S0025315414001234

Oren, A. (2011). Thermodynamic limits to microbial life at high salt concentrations. Environ. Microbiol. 13, 1908-1923. https://doi.org/ 10.1111/j.1462-2920.2010.02365.x

Pachiadaki, M.G., Taylor, C., Oikonomou, A., Yakimov, M.M., Stoeck, T., and Edgcomb, V. (2016). In situ grazing experiments apply new technology to gain insights into deep-sea microbial food webs. Deep Sea Res Part 2: Top Stud Oceanogr. 129, 223-231. https://doi.org/10.1016/ j.dsr2.2014.10.019

Pachiadaki, M.G., Yakimov, M.M., LaCono, V., Leadbetter, E., and Edgcomb, V. (2014). Unveiling microbial activities along the halocline of Thetis, a deep-sea hypersaline anoxic basin. ISME J 8, 2478-2489. https://doi.org/10.1038/ismej.2014.100

Patthoff, D.A., and Kattenhorn, S.A. (2011). A fracture history on Enceladus provides evidence for a global ocean. Geophys. Res. Lett. 38, L18201. http://dx.doi.org/10.1029/2011GL048387

Pautot, G., Guennoc, P., Coutelle, A., and Lyberis, N. (1984). Discovery of a large brine deep in the northern Red Sea. Nature. 310, 133-136. https://doi.org/10.1038/310133a0

Payler, S.J., Biddle, J.F., Coates, A.J., Cousins, C.R., Cross, R.E., Cullen, D.C., Downs, M.T., Direito, S.O., Edwards, T., Gray, A.L., Genis, J., Gunn, M., Hansford, G.M., Harkness, P., Holt, J., Josset, J.L., Li, X., Lees, D.S., Lim, D.S.S., Mchugh, M., Mcluckie, D., Meehan, E., Paling, S.M. Souchon, A., Yeoman, L., and Cockell, C.S. (2017). Planetary science and exploration in the deep subsurface: results from the MINAR 
Program, Boulby Mine, UK. Int. J. Astrobiol. 16(2), 114-129. https:// doi.org/10.1017/S1473550416000045

Postberg, F., Kempf, S., Schmidt, J., Brilliantov, N., Beinsen, A., Abel, B., Buck, U., and Srama, R. (2009). Sodium salts in E-ring ice grains from an ocean below the surface of Enceladus. Nature. 459, 1098-1101. https://doi.org/10.1038/nature08046

Postberg, F., Schmidt, J., Hillier, J., Kempf, S., and Srama, R. (2011). A salt-water reservoir as the source of a compositionally stratified plume on Enceladus. Nature. 474, 620-622. https://doi.org/10.1038/nature10175

Prieto-Ballesteros, O., Rodriguez, N., Kargel, J.S., Kessler, C.G., Amils, R., and Remolar, D.F. (2003). Tirez lake as a terrestrial analog of Europa. Astrobiology 3, 863-877. https://doi.org/10.1089/153110703322736141

Quick, L.C., and Marsh, B.D. (2015). Constraining the thickness of Europa's water-ice shell: Insights from tidal dissipation and conductive cooling. Icarus 253, 16-24. https://doi.org/10.1016/j.icarus.2015.02.016

Robinson, J.M. and Mikucki, J.A. (2018). Occupied and empty regions of the space of extremophile parameters. In Habitability of the Universe Before Earth, R. Gordon, ed. (London, UK: Imperial College Press), pp. 199-230. https://doi.org/10.1016/B978-0-12-811940-2.00009-5

Rodondi, G., Andreis, C., Pellegrini, S., Brusa, T., Del Puppo, E., Ferrari, A., and Cita, M.B. (1996). Presenza di batteri in bacini anossici del Mediterraneo orientale: indagini preliminari. Rend. Fis. Acc.Lincei 7, 63-78. https://doi.org/10.1007/BF03001700

Ross, M.N. and Schubert, G. (1987). Tidal heating in an internal ocean model of Europa. Nature. 325, 133-134. https://doi.org/ $10.1038 / 325133 a 0$

Roth, L., Saur, J., Retherford, K.D., Strobel, D.F., Feldman, P.D., Mcgrath, M.A., and Nimmo, F. (2014). Transient Water Vapor at Europa's South Pole. Science. 343, 171-174. https://doi.org/10.1126/science.1247051

Roveri, M., Flecker, R., Krijgsman, W., Lofi, J., Lugli, S., Manzi, V., Sierro, F.J., Bertini, A., Camerlenghi, A., De Lange, G., Govers, R., Hilgen, F.J., Hübscher, C., Meijer, P.T., and Stoica, M. (2014). The Messinian Salinity Crisis: past and future of a great challenge for marine sciences. Mar. Geol. 352, 25-58. https://doi.org/10.1016/j.margeo.2014.02.002

Røy, H., Kallmeyer, J., Adhikari, R.R., Pockalny, R., Jørgensen, B.B., and D'Hondt, S. (2012). Aerobic microbial respiration in 86-million-year-old deep-sea red clay. Science. 336, 922-925. https://doi.org/10.1126/ science.1219424

Russell, M.J., Murray, A.E., and Hand, K.P. (2017). The possible emergence of life and differentiation of a shallow biosphere on irradiated icy worlds: the example of Europa. Astrobiology. 17, 1265-1273. https:// doi.org/10.1089/ast.2016.1600

Rutishauser, A., Blankenship, D.D., Sharp, M., Skidmore, M.L., Greenbaum, J.S., Grima, C., Schroeder, D.M., Dowdeswell, J.A., and Young, D.A. (2018). Discovery of a hypersaline subglacial lake complex 
beneath Devon Ice Cap, Canadian Arctic. Sci. Adv. 4, eaar4353. https:// doi.org/10.1126/sciadv.aar4353

Sagar, S., Esau, L., Hikmawan, T., Antunes, A., Holtermann, K., Stingl, U., Bajic, V.B., and Kaur, M. (2013a). Cytotoxic and apoptotic evaluations of marine bacteria isolated from brine-seawater interface of the Red Sea. BMC Complement. Altern. Med. 13, 29. https://doi.org/ 10.1186/1472-6882-13-29

Sagar, S., Esau, L., Holtermann, K., Hikmawan, T., Zhang, G., Stingl, U., Bajic, V.B., and Kaur, M. (2013b). Induction of apoptosis in cancer cell lines by the Red Sea brine pool bacterial extracts. BMC Complement. Altern. Med. 13, 344. https://doi.org/10.1186/1472-6882-13-344

Sass, A.M., Sass, H., Coolen, M.J., Cypionka, H., and Overmann, J. (2001). Microbial communities in the chemocline of a hypersaline deepsea basin (Urania basin, Mediterranean Sea). Appl. Environ. Microbiol. 67(12), 5392-5402. https://doi.org/10.1128/AEM.67.12.5392-5402.2001

Sass, A.M., McKew, B.A., Sass, H., Fichtel, J., Timmis, K.N., and McGenity, T.J. (2008). Diversity of Bacillus-like organisms isolated from deep-sea hypersaline anoxic sediments. Saline Systems. 4, 8. https://doi.org/ 10.1186/1746-1448-4-8

Schmidt, M., Al-Farawati, R., and Botz, R. (2015). Geochemical classification of brine-filled Red Sea deeps. In The Red Sea, N.M.A. Rasul and I.C.F. Stewart, eds. (Berlin, Germany: Springer), pp. 219-233.

Schmidt, M., Botz, R., Faber, E., Schmitt, M., Poggenburg, J., GarbeSchönberg, D., and Stoffers, P. (2003). High-resolution methane profiles across anoxic brine-seawater boundaries in the Atlantis-II, discovery, and Kebrit deeps (Red Sea). Chem. Geol. 200, 359-375. https://doi.org/ 10.1016/S0009-2541(03)00206-7

Schubert, B., Lowenstein, T., Timofeeff, M., and Parker, M. (2010). Halophilic Archaea cultured from ancient halite, Death Valley, California. Environ. Microbiol. 12, 440-454. https://doi.org/10.1111/j. 1462-2920.2009.02086.x

Sekine, Y., Shibuya, T., Postberg, F., Hsu, H.W., Suzuki, K., Masaki, Y., Kuwatani, T., Mori, M., Hong, P.K., Yoshizaki, M., Tachibana, S., and Sirono, S. (2015). High-temperature water-rock interactions and hydrothermal environments in the chondrite-like core of Enceladus. Nat. Commun. 6, 8604. https://doi.org/10.1038/ncomms9604

Seyfried Jr, W.E. (1987). Experimental and theoretical constraints on hydrothermal alteration processes at mid-ocean ridges. Ann. Rev. Earth Planet. Sci. 15(1), 317-335. https://doi.org/10.1146/annurev.ea. 15.050187.001533

Shokes, R.F., Trabant, P.K., Presley, B., and Reid, D.F. (1977). Anoxic, hypersaline basin in the northern Gulf of Mexico. Nature 196, 1443-1446. https://doi.org/10.1126/science.196.4297.1443

Showman, A.P., and Malhotra, R. (1999). The Galilean satellites. Science 286, 77-84. https://doi.org/10.1126/science.286.5437.77

Siam, R., Mustafa, G.A., Sharaf, H., Moustafa, A., Ramadan, A.R., Antunes, A., Bajic, V.B., Stingl, U., Marsis, N.G., Coolen, M.J., Sogin, M., 
Ferreira, A.J.S., and El Dorry, H. (2012). Unique prokaryotic consortia in geochemically distinct sediments from Red Sea Atlantis II and Discovery Deep brine pools. PloS one. 7, e42872. https://doi.org/10.1371/ journal.pone.0042872

Sorokin, D.Y., Tourova, T.P., Lysenko, A.M., and Muyzer, G. (2006). Diversity of culturable halophilic sulfur-oxidizing bacteria in hypersaline habitats. Microbiology. 152, 3013-3023.

Sorokin, D.Y., Kublanov, I.V., Gavrilov, S.N., Rojo, D., Roman, P., Golyshin, P.N., Slepak, V.Z., Smedile, F., Ferrer, M., Messina, E., La Cono, V., and Yakimov, M.M. (2016). Elemental sulfur and acetate can support life of a novel strictly anaerobic haloarchaeon. ISME J. 10(1), 240-252. https:// doi.org/10.1038/ismej.2015.79

Sorokin, D.Y., Makarova, K., Abbas, B., Ferrer, M., Golyshin, P.N., Galinski, E.A., Ciordia, S., Mena, M.C., Merkel, A.Y., Wolf, Y.I., van Loosdrecht, M.C.M., and Koonin, E.V. (2017). Discovery of extremely halophilic methyl-reducing euryarchaea provides insight into the evolutionary origin of methanogenesis. Nature Microbiol. 2, 17081. https://doi.org/10.1038/ nmicrobiol.2017.81

Sparks, W.B., Hand, K.P., Mcgrath, M.A., Bergeron, E., Cracraft, M., and Deustua, S.E. (2016). Probing for evidence of plumes on Europa with HST/STIS. Astrophysical J. 829, 121. http://dx.doi.org/ 10.3847/0004-637X/829/2/121

Spencer, J.R., and Nimmo, F. (2013). Enceladus: An Active Ice World in the Saturn System. Annu. Rev. Earth Planet. Sci. 41, 693-717. https:// doi.org/10.1146/annurev-earth-050212-124025

Spencer, J.R., Tamppari, L.K., Martin, T.Z., and Travis, L.D. (1999). Temperatures on Europa from Galileo photopolarimeter-radiometer: Nighttime thermal anomalies. Science. 284, 1514-1516. https://doi.org/ 10.1126/science.284.5419.1514

Spencer, J.R., Pearl, J.C., Segura, M., Flasar, F.M., Mamoutkine, A., Romani, P., Buratti, B.J., Hendrix, A.R., Spilker, L.J., and Lopes, R.M.C. (2006). Cassini encounters Enceladus: Background and the discovery of a south polar hot spot. Science. 311, 1401-1405. https://doi.org/10.1126/ science. 1121661

Speth, D. R., Lagkouvardos, I., Wang, Y., Qian, P. Y., Dutilh, B. E., and Jetten, M. S. (2017). Draft genome of Scalindua rubra, obtained from the interface above the discovery deep brine in the Red Sea, sheds light on potential salt adaptation strategies in anammox bacteria. Microb. Ecol. 74, 1-5. https://doi.org/10.1007/s00248-017-0929-7

Squyres, S.W., Reynolds, R.T., Cassen, P.M., and Peale, S.J. (1983a). The evolution of Enceladus. Icarus. 53, 319-331. https://doi.org/ 10.1016/0019-1035(83)90152-5

Squyres, S.W., Reynolds, R.T., Cassen, P.M., and Peale, S.J. (1983b). Liquid water and active resurfacing on Europa. Nature. 301, 225-226. https://doi.org/10.1038/301225a0

Steinle, L., Knittel, K., Felber, N., Casalino, C., Lange, G., Tessarolo, C., Stadnitskaia, A., Damsté, J.S.S., Zopfi, J., Lehmann, M.F., Treude, T., 
and Niemann, H. (2018). Life on the edge - active microbial communities in the Kryos $\mathrm{MgCl}_{2}$-brine basin at very low water activity. ISME J. 12, 1414-1426. https://doi.org/10.1038/s41396-018-0107-z

Stevenson, A., Cray, J.A., Williams, J.P., Santos, R., Sahay, R., Neuenkirchen, N., McClure, C.D., Grant, I.R., Houghton, J.D., Quinn, J.P., Timson, D.J., Patil, S.V., Singhal, R.S., Antón, J., Dijksterhuis, J., Hocking, A.D., Lievens, B., Rangel, D.E.N., Voytek, M.A., GundeCimerman, N., Oren, A., Timmis, K.N., McGenity, T.J., and Hallsworth, J.E. (2015). Is there a common water-activity limit for the three Domains of life? ISME J. 9, 1333-1351. https://doi.org/10.1038/ismej.2014.219

Stevenson, A., Hamill, P.G., O'Kane, C.J., Kminek, G., Rummel, J.D., Voytek, M.A., Dijksterhuis, J., and Hallsworth, J.E. (2016). Aspergillus penicillioides differentiation and cell division at 0.585 water activity. Environ. Microbiol. 19, 687-697. https://doi.org/10.1111/1462-2920.13597

Stoffers, P., Moammar, M., Abu-Ouf, M., Ackermand, D., Alassif, O., AlHazim, Y., Boldt, S., Botz, R., Eder, W., El-Garafi, A., El-Mamoney, M., Fleitmann, D., Garbe-Schönberg, D., Geiselhart, S., Goedecke, D., Hartmann, M., Klauke, S., Moussa, K., Mühlhan, N., Mühlstrasser, T., Poggenburg, J., Rehder, W., Schmidt, M., Schmitt, M., Schoeps, D., Scholten, J., Shbalaby, M., Wismann, A., and Yohannes, E. (1998). Cruise Report SONNE 121, Red Sea. Hydrography, Hydrothermalism and Paleoceanography in the Red Sea, No. 88. (Kiel, Germany: Geologisch-Paläontologisches Institut und Museum, Christian-AlbrechtsUniversität der Universität Kiel). https://doi.org/10.2312/reports-gpi. 1998.88

Tamburini, C., Boutrif, M., Garel, M., Colwell, R.R., and Deming, J.W. (2013). Prokaryotic responses to hydrostatic pressure in the ocean - a review. Environ. Micro. 15, 1262-1274. https://doi.org/ 10.1111/1462-2920.12084

Taubner, R.S., Pappenreiter, P., Zwicker, J., Smrzka, D., Pruckner, C., Kolar, P., Bernacchi, S., Seifert, A.H., Krajete, A., Bach, W., and Peckmann, J. (2018). Biological methane production under putative Enceladus-like conditions. Nat. Commun. 9, 748. https://doi.org/10.1038/ s41467-018-02876-y

Tsimplis, M.N., and Baker, T.F. (2000). Sea level drop in the Mediterranean Sea: an indicator of deep water salinity and temperature changes? Geophys. Res. Lett. 27, 1731-1734

Torreblanca, M., Rodriguez-Valera, F., Juez, G., Ventosa, A., Kamekura, M., and Kates, M. (1986). Classification of non-alkaliphilic halobacteria based on numerical taxonomy and polar lipid composition, and description of Haloarcula gen. nov. and Haloferax gen. nov. System. Appl. Microbiol. 8, 89-99. https://doi.org/10.1016/ S0723-2020(86)80155-2

Trüper, H. G. (1969). Bacterial sulfate reduction in the Red Sea hot brines In Hot brines and recent heavy metal deposits in the Red Sea, E.T. Degens and D.A. Ross, eds. (New York, N.Y., USA: Springer-Verlag), pp 263-271. 
Van der Wielen, P.W.J.J., Bolhuis, H., Borin, S., Daffonchio, D., Corselli, C., Giuliano, L., de Lange, G.J., Varnavas, S.P., Thompson, J., Tamburini, C., Marty, D., McGenity, T.J., Timmis, K.N., and BioDeep Scientific Party. (2005). The enigma of prokaryotic life in deep hypersaline anoxic basins. Science. 307, 121-123. https://doi.org/10.1126/science.1103569

Vance, S. and Goodman J. (2009). Oceanography of an ice-covered moon.In Europa, R.T. Pappalardo, W.B. McKinnon, and K.K. Khurana, eds. (Tucson, AZ, USA: University of Arizona Press), pp. 459-482.

Vandaele, A.C., Neefs, E., Drummond, R., Thomas, I.R., Daerden, F., Lopez-Moreno, J.J., Rodriguez, J., Patel, M.R., Bellucci, G., Allen, M., Altieri, F., Bolséea, D., Clancy, t., Delanoyea, S., Depiessea, C., Cloutisg, E., Fedorovah, A., Formisano, V., Funke, B., Fussen, D., Geminale, A., Gérard, J.-C., Giuranna, M., Ignatiev, N., Kaminski, J., Karatekin, O., Lefèvre, F., López-Puertas, M., López-Valverde, M., Mahieux, A., McConnell, J., Mumma, M., Neary, L., Renotte, E., Ristic, B., Robert, S., Smith, M., Trokhimovsky, S., Vander Auwera, J., Villanueva, G., Whiteway, J., Wilqueta, V., Wolff, M., and the NOMAD Team. (2015). Science objectives and performances of NOMAD, a spectrometer suite for the ExoMars TGO mission. Planet. Space Sci. 119, 233-249. https://doi.org/10.1016/j.pss.2015.10.003

Vengosh, A., de Lange, G.J., and Starinsky, A. (1998). Boron isotope and geochemical evidence for the origin of Urania and Bannock brines at the eastern Mediterranean: effect of water-rock interactions. Geochim. Cosmochim. Acta. 62, 3221-3228. https://doi.org/10.1016/ S0016-7037(98)00236-1

Vestheim, H., and Kaartvedt, S. (2016). A deep sea community at the Kebrit brine pool in the Red Sea. Mar. Biodivers. 46, 59-65. https:// doi.org/10.1007/s12526-015-0321-0

Vetriani, C., Crespo-Medina, M., and Antunes, A. (2014). The family Salinisphaeraceae. In The Prokaryotes: Gammaproteobacteria $4^{\text {th }}$ Edition, E. Rosenberg, E.F. DeLong, S. Lory, E. Stackebrandt, and F. Thompson, eds. (Berlin, Germany: Springer), pp. 591-596. https:// doi.org/10.1007/978-3-642-38922-1_296

Waite, J.H., Glein, C.R., Perryman, R.S., Teolis, B.D., Magee, B.A., Miller, G., Grimes, J., Perry, M.E., Miller, K.E., Bouquet, A., Lunine, J.I., Brockwell, T., and Bolton, S.J. (2017). Cassini finds molecular hydrogen in the Enceladus plume: Evidence for hydrothermal processes. Science. 356, 155-159. https://doi.org/10.1126/science.aai8703

Watson, S.W. and Waterbury, J.B. (1969). The sterile hot brines of the Red Sea. In Hot Brines and Recent Heavy Metal Deposits in the Red Sea. E.T. Degens D.A. and Ross, eds. (New York, NY, USA: Springer-Verlag), pp. 272-281. https://doi.org/10.1007/978-3-662-28603-6_27

Weber, W.W. and Gurskii, Y.N. (1982). Maltene formation in present sediments of the Kebrit brine depressions of the Red Sea. Geologiya Nefti Gaza. 1, 29-33.

Werner, J., Ferrer, M., Michel, G., Mann, A.J., Huang, S., Juarez, S., Ciordia, S., Albar, J.P., Alcaide, M., La Cono, V., Yakimov, M.M., Antunes, 
A., Taborda, M., da Costa, M.S., Hai, T., Glöckner, F.O., Golyshina, O.V., Golyshin, P.N., Teeling, H., and the MAMBA Consortium. (2014). Halorhabdus tiamatea: Proteogenomics and glycosidase activity measurements identify the first cultivated euryarchaeon from a deep-sea anoxic brine lake as potential polysaccharide degrader. Environ. Microbiol. 16, 2525-2537. https://doi.org/10.1111/1462-2920.12393

Yao, F., and Hoteit, I. (2018). Rapid red sea deep water renewals caused by volcanic eruptions and the North Atlantic Oscillation. Science Adv. 4, 5637. https://doi.org/10.1126/sciadv.aar5637

Yakimov, M.M., Giuliano, L., Cappello, S., Denaro, R., Golyshin, P.N. (2007a). Microbial community of a hydrothermal mud vent underneath the deep-sea anoxic brine lake Urania (Eastern Mediterranean). Origins Life Evol. B 37, 177-188. https://doi.org/10.1007/s11084-006-9021-x

Yakimov, M.M., La Cono, V., Denaro, R., D'Auria, G., Decembrini, F., Timmis, K.N., Golyshin, P.N., and Giuliano, L. (2007b). Primary producing prokaryotic communities of brine, interface and seawater above the halocline of deep anoxic lake L'Atalante, Eastern Mediterranean Sea. ISME J. 1, 743-755. https://doi.org/10.1038/ismej. 2007.83

Yakimov, M.M., La Cono, V., Slepak, V.Z., La Spada, G., Arcadi, E., Messina, E., Borghini, M., Monticelli, L.S., Rojo, D., Barbas, C., Golyshina, O.V., Ferrer, M., Golyshin, P.N., and Giuliano, L. (2013). Microbial life in the Lake Medee, the largest deep-sea salt-saturated formation. Sci. Rep. 3, 3554. https://doi.org/10.1038/srep03554

Yakimov, M.M., La Cono, V., Spada, G.L., Bortoluzzi, G., Messina, E., Smedile, F., Arcadi, E., Borghini, M., Ferrer, M., Schmitt-Kopplin, P., Hertkorn, N., Cray, J.A., Hallsworth, J.E., Golyshin, P.N., and Giuliano, L. (2015). Microbial community of the deep-sea brine Lake Kryos seawaterbrine interface is active below the chaotropicity limit of life as revealed by recovery of mRNA. Environ. Microbiol. 17, 364-382. https://doi.org/ 10.1111/1462-2920.12587

Yancey, P.H. (2004). Compatible and counteracting solutes: protecting cells from the Dead Sea to the deep sea. Sci. Prog. 87(1), 1-24. https:// doi.org/10.3184\%2F003685004783238599

Yayanos, A.A. (1986). Evolution and ecological implications of the properties of deep-sea barophilic bacteria. Proc. Natl. Acad. Sci. USA 83, 9542-9546. https://doi.org/10.1073/pnas.83.24.9542

Zajc, J., Džeroski, S., Kocev, D., Oren, A., Sonjak, S., Tkavc, R., and Gunde-Cimerman, N. (2014). Chaophilic or chaotolerant fungi: a new category of extremophiles? Front. Microbiol. 5, 708. https://doi.org/ 10.3389/fmicb.2014.00708

Zhang, G., Haroon, M.F., Zhang, R., Hikmawan, T., and Stingl, U. (2016a). Draft genome sequence of Pseudoalteromonas sp. strain XI10 isolated from the brine-seawater interface of Erba Deep in the Red Sea. Genome Announc. 4, e00109-16. https://doi.org/10.1128/genomea.00109-16

Zhang, G., Haroon, M.F., Zhang, R., Hikmawan, T., and Stingl, U. (2016b). Draft genome sequences of two Thiomicrospira strains isolated from the 
brine-seawater interface of Kebrit Deep in the Red Sea. Genome Announc. 4, e00110-16. https://doi.org/10.1128/genomeA.00110-16

Zhang, G., Haroon, M.F., Zhang, R., Dong, X., Liu, D., Xiong, Q., Xun, W., Dong, X., and Stingl, U. (2017a). Ponticoccus marisrubri sp. nov., a moderately halophilic marine bacterium of the family Rhodobacteraceae. Int. J. Syst. Evol. Microbiol. 67, 4358-4364. https://dx.doi.org/10.1099/ ijsem.0.002280

Zhang, G., Haroon, M.F., Zhang, R., Dong, X., Wang, D., Liu, Y., Xun, W., Dong, X., and Stingl, U. (2017b). Ruegeria profundi sp. nov. and Ruegeria marisrubri sp. nov., isolated from the brine-seawater interface at Erba Deep in the Red Sea. Int. J. Syst. Evol. Microbiol. 67, 4624-4631. https://dx.doi.org/10.1099/ijsem.0.002344

Zhang, G., Gu, J., Zhang, R., Rashid, M., Haroon, M.F., Xun, W., Ruan, Z., Dong, X. and Stingl, U. (2017c). Haloprofundus marisrubri gen. nov., sp. nov., an extremely halophilic archaeon isolated from a brine-seawater interface. Int. J. Syst. Evol. Microbiol. 67, 9-16. https://dx.doi.org/ 10.1099/ijsem.0.001559

Zhang, G., Dong, X., Sun, Y., Antunes, A., Hikmawan, T., Haroon, M.F., Wang, J., and Stingl, U. (2020). Haloferax profundi sp. nov. and Haloferax marisrubri sp. nov., isolated from the Discovery Deep brineseawater interface in the Red Sea. Int. J. Syst. Evol. Microbiol. (submitted).

Zolotov, M.Y. (2007). An oceanic composition on early and today's Enceladus. Geophys. Res. Lett. 34, L23203. https://doi.org/ 10.1029/2007GL031234

Zolotov, M.Y. and Kargel, J.S. (2009). On the chemical composition of Europa's icy shell, ocean, and underlying rocks. In Europa, R.T. Pappalardo, W.B. McKinnon, and K.K. Khurana, eds. (Tucson, AZ, USA: University of Arizona Press), pp. 431-458. 
caister.com/astro 